the Total Environment

Elsevier Editorial System(tm) for Science of

Manuscript Draft

Manuscript Number: STOTEN-D-13-03175R2

Title: Fire severity, residuals and soil legacies affect regeneration of Scots pine in the Southern Alps

Article Type: Research Paper

Keywords: Crown fire; Disturbance ecology; FOFEM; Pinus sylvestris L.; Soil aggregate stability; Soil quality

Corresponding Author: Dr. Giorgio Vacchiano, Ph.D.

Corresponding Author's Institution: Università di Torino

First Author: Giorgio Vacchiano, Ph.D.

Order of Authors: Giorgio Vacchiano, Ph.D.; Silvia Stanchi, PhD; Giulia Marinari, MS; Davide Ascoli, PhD; Ermanno Zanini, MS; Renzo Motta, PhD

Abstract: Regeneration of non fire-adapted conifers following crown fires on the European Alps is often delayed or unsuccessful. Fire may limit establishment by eliminating seed trees, altering soil properties, or modifying microsite and soil conditions via disturbance legacies. However, the effect of soil legacies on post-fire establishment has rarely been discussed. We analyzed the abundance of scots pine regeneration in a 257 ha wildfire in an inner-alpine forest. Our aims were (1) to model fire intensity at the soil surface and topsoil heating along a gradient of increasing fire severities; (2) to assess the differences in soil properties along the fire severity gradient; (3) to model the effect of disturbance and soil legacies on the density of pine seedlings. We reconstructed fire behavior and soil heating with the First Order Fire Effects Model (FOFEM), tested the effect of fire severity on soils by nonparametric distributional tests, and modeled seedling density as a function of site, disturbance and soil legacies by fitting a GLM following a variable selection procedure. Topsoil heating differed markedly between the moderate and high severity fires, reaching temperatures high enough to strongly and permanently alter soil properties only in the latter. High fire severity resulted in decreased soil consistency and wet aggregate stability. Burned soils had lower organic matter and cations than those unburned. Pine seedlings favored low-fertility, eroded, and chemically poor sites. Establishment was facilitated by the presence of coarse woody debris, but hampered by increasing distance from the seed source. These results suggest that in dry, inner-alpine valleys, fire residuals and soil legacies interact in determining the success of scots pine re-establishment. High severity fire can promote favorable soil conditions, but distance from the seed source and high evaporation rates of bare soils must be mitigated in order to ensure a successful restoration. 
Response to Reviewers: All figures have been uploaded in TIFF format. 
Science of the Total Environment

Editorial Office

\section{Grugliasco (Italy), 25 ${ }^{\text {th }}$ September 2013}

\section{Dear Editor,}

I enclose to the present letter the following manuscript for submission to your journal: "Fire severity, residuals and soil legacies affect regeneration of Scots pine in the Southern Alps".

The article is original, has not been considered for publication elsewhere in its current version, and has been read and approved by all authors.

The submission consists of this cover letter, the title page, highlights, manuscript text with references, tables, and figure captions, and 4 figures in separate files.

I believe the paper's topic falls neatly into the scope of the journal, since it details the combined effect of several environmental drivers (disturbance, soil, and site characteristics) on the regeneration of Scots pine, a tree species highly relevant for several ecosystem services in the Alps. My co-authors and I would be delighted to have our paper appear in your journal.

I thank you and the reviewers in advance for your efforts in evaluating and critiquing this manuscript. I look forward to your review.

\section{Sincerely,}

Giorgio Vacchiano (Corresponding author)

Tel.: +39011 6705536. Fax: +390116705546.

Email: giorgio.vacchiano@unito.it

Department of Agricultural, Forest and Food Sciences - University of Turin

via L. da Vinci 44, 10095 Grugliasco (TO), Italy 


\section{Reviewer \#1:}

1. Given that sample size is relatively modest (5 plots per severity level) there might be potentially a bias in results due to spurious reasons, e.g. potential differences for seed arrival to different sites. Perhaps authors should provide additional information that help to clarify robustness of the sampling design.

EDITED: Clarifications on the sampling design and pre-fire variability were given in response to Reviewer's \#2 requests (see below). Also, potential differences in seed arrival were accounted for by including distance from seed trees as a predictor in all analyses.

2. It might be appropriate to expand the information related with the role of post-fire legacies not only on plant regeneration, but also in ecosystem functioning... the introduction section pays little attention to that point. Additional papers merit citation in case the authors accept to expand a bit the Introduction section with information related to the effect of post-fire legacies on ecosystems functioning.

ADDED (in Introduction): "Legacies play a key role in facilitating regeneration establishment, increasing plant growth, and promoting ecosystem functioning, e.g., in terms of nutrient availability, diversity and abundance of microsites, soil respiration and biotic community functioning, in many Mediterranean, temperate, boreal and tropical forest ecosystems throughout the world (e.g., Beard et al., 2005; Castro et al., 2012; Griffin and Turner, 2012; MarañónJiménez et al., 2013; Marañón-Jiménez and Castro, 2013; Peterson and Leach, 2008)."

3. Section 4.3 of the Discussion is presented in an unusual way... I suggest to reorganize that part of the text to make it readable.

EDITED section 4.3 and reorganised as continuous-flow text.

4. There is certain repetition of the Discussion with the Result section. The Discussion could be slightly shortened to make it more direct and concise.

REMOVED all results from the discussion, unless in paragraph 4.4: we feel that reminding the reader about model coefficients for soil variables would be important in this part, that summarized all previous analyses.

5. Lines 329-331. This sentence is not clear to me. Why to assume that logging did not alter the legacies?

DELETED the sentence.

6. I suggest the authors to consider some recent papers very related to this work and that provide relevant information to discuss their results and/or to set the background.

ADDED the suggested references where relevant in the text.

\section{Reviewer \#2:}

7. Detection rate can be expected to vary between the types of plots compared by the authors (...) The authors could address this issue by quantifying detection rate under their search protocol at a range of site types, and then including estimated detection as a covariate in their analyses. [reported both in general comments and at line 286]

ADDED (in Methods): "Seedlings were searched visually by stooping to the ground from inside each plot for at least 30 minutes. Areas around and below shrubs and woody debris were searched as well, in order to minimize detection errors (Hancock et al., 2009)."

We understand that this method is more destructive than searching from outside the plot, but we did not intend to repeat the measurement in a future time.

8. Even if close together, plots in different fire types may have had different site conditions prior to the fire, as well as differences in fire behaviour. In fact you might expect that changes in fire behaviour over short distances would partly reflect changes in pre-existing site characteristics (as well as other aspects like changes in weather and fire control activities). Some of the differences, for example in soil properties, that they attribute to differences in fire behaviour, may have 
already been present before the fire. Clearly, this in an observational study where such differences cannot be controlled, but nevertheless the authors should describe, quantify and discuss some measurable differences, to help with the interpretation of the study. They could do this by (i) examining forest structure prior to the fire using older aerial or satellite images; and (ii) comparing topographical variables between areas where different fire behaviour occurred. Forest properties prior to the fire such as stand density or species composition, and topographical variables such as aspect and altitude, could be quantified across the different types of fire behaviour, and presented as part of the site description. Variation across the area that pre-dated the fire should then be discussed when interpreting the results, to help understand the extent to which the results reflect fire behaviour alone, or some combination of fire behaviour and prior site characteristics. [reported in general comments and at lines 136 and 320].

ADDED (in Methods): "In order to rule out possible pre-fire differences in stand structure, we sampled, averaged, and compared the number and root collar diameter (rcd) of live and dead mature trees and of all stumps in each plot (only individuals with $\mathrm{rcd}>7.5 \mathrm{~cm}$ )."

ADDED (in Results): "Pre-fire stand density was similar under all fire severity levels (Table 3 ). However, pre-fire mean tree diameter was higher under increasing fire severities. This difference might have been conducive to a change in fire behavior, influencing surface and crown fuel continuity, but should not be influential on post-fire soil and regeneration dynamics. "

ADDED (in Results): "Pre-fire soil conditions were unknown. However, topographic variables (elevation, slope, and aspect) and stand density exhibited a comparable range across fire severity levels (Table 3 ), therefore we could rule out bias due to such effects. "

ADDED relevant variables in Table 3 (elevation, aspect, pre-fire tree density and average diameter)

9. Line 6. The authors need to consider the fact that the readership of this journal will not be familiar with some of the typical fire jargon (...) This is particularly important in the abstract (...). How about some alternatives (...)?

EDITED: we followed suggestions of Reviewer 2 and changed in the abstract several terms (eg. non- serotinous / less fire-adapted; stand-replacing fires / crown fires; canopy seed bank / seed trees). In the text, when using fire jargon, we provided references or definition, as suggested.

10. line 19. replace 'critical value' with 'temperatures high enough to strongly and permanently alter soil properties' or similar.

\section{EDITED}

11. line 259. This is the first time you use this threshold - introduce this threshold and explain it, earlier in the paper [reported also at lines 307-308]

ADDED explicit mention of the two thresholds in the Introduction ("e.g., $60^{\circ} \mathrm{C}$ for the destruction of the microbial pool, and $220^{\circ} \mathrm{C}$ for incipient structural degradation")

12. Table 1. Interesting Table but this level of detail not needed here - place in Supplementary Material and refer in text to two key temperature thresholds around 60 and 220 degrees $\mathrm{C}$.

NOT EDITED. We feel that a summary table could be of use for many other studies, and would prefer not to relegate it to the Supplementary Material. The two important thresholds have been highlighted in bold.

13. line 36. Also the most widespread pine in the world (Mirov 1967).

\section{ADDED}

14. line 39. Susceptibility.

\section{EDITED}

15. line 41. Rather than this PhD thesis, for a more widely available source for a general view on Scots pine, other pines and their associated fire regimes, see Agee (1998).

ADDED (but left reference to Hille 2006 alongside the others)

16. line 41. You could insert a sentence here (before 'However'), providing more international context on Scots pine and fire. After all, this is the most widely distributed pine in the world. e.g. you 
could refer to studies of Scots pine and fire both in terms of natural fire regimes (Niklasson \& Granstrom 2000) and the use of management fire to promote Scots pine (Ostlund et al 1997; Hancock et al 2009).

ADDED: "Fire regimes in Scots pine were described as moderate-severity (Agee, 1998). The species has been observed to resist multiple fires (Storaunet et al. 2013), and to regenerate successfully in low-frequency fire regimes, in both boreal and continental European forests (Niklasson et al., 2010; Hille, 2006), e.g., also following the application of prescribed burning (Hancock et al., 2009, Hille and Den Ouden, 2004). "

17. line 43. It is implicit throughout your study that restored forest cover is desired after wildfire. You could state here why this is the case. [reported also at line 61: here or earlier you could state why a return of former soil and forest type is desired in areas like your study area]

ADDED: "In order to sustain the flow of ecosystem services provided by the mountain forest, e.g., protection from gravitational hazards and recreation, rapid restoration of forest cover is often desired following catastrophic disturbances (Dorren et al., 2004)."

18. line 48. You have a particularly usage of fire 'severity' and 'intensity' following Keeley. This is more specific than use in common language. Here you could more explicitly introduce how you will be using these terms: e.g. 'fire severity' as tree mortality and organic soil layer consumed and 'fire intensity' being Byrams (1959) fireline intensity

ADDED: "Fire intensity, i.e., the energy release from organic matter combustion per unit volume, times the velocity at which the energy is moving $(\mathrm{kW} / \mathrm{m} 2) "$. This definition after Keeley (2009) is different than Byram's fireline intensity $(\mathrm{kW} / \mathrm{m} / \mathrm{sec})$, and is also the output of FOFEM.

19. lines 113 and 127 : intensity and severity cannot be used in their more general sense or it gets confusing

NON EDITED at line 113, since this is the proper meaning of severity that we use throughout the paper and define in the introduction.

DELETED paragraph at line 127.

20. line 50. The term 'fire residual' is often reserved just for the patches of unburnt forest (e.g. Gandhi et al 2001) whereas here you are also using it for what would commonly be called 'legacies' e.g. individual structures like downed logs.

EDITED: "disturbance residuals" were replaced by "disturbance (and soil) legacies" throughout the paper.

21. line 52. Include soil references from a wider range of regions, to illustrate that many of these issues are applicable quite widely around the world. One you could consider from a UK perspective, is Mallik et al 1984.

\section{ADDED}

22. line 55. Mention effects of fire on fungi including mycorrhizal species that associate with trees and could be important in pine regeneration processes (e.g. Bastias et al 2006, Curveleski et al 2011).

\section{ADDED}

23. line 61 . Are permanent changes in soil structure a bad thing? Or might they be acceptable in some circumstances e.g. where a fire regime naturally includes occasional severe fires? (...)

ADDED: "potentially delaying or preventing the establishment of tree regeneration", which is the main aim here as more clearly stated in the new revised version of the manuscript.

24. line 63. A useful reference on this area (rather than Grubb, which is a very general reference) is Schimmel \& Granstrom 1996.

\section{ADDED}

25. line 68. In what ways might your study change the way we plan for successful regeneration after wildfire? To what extent might it change not just what we know, but what we do?

EDITED (in Conclusions): "Fuel reduction treatments can be used to mitigate fire behavior and effects, such as in inner-alpine Scots pine stands subject to high fire risk. However, in the Alps it 
is difficult and/or socially unaccepted to create fuelbreaks large enough to slow down intense crown fires (Bovio, 2000). Therefore, the spatial otpimization of treated areas (e.g., Agee and Skinner, 2005) could be based on other criteria, such as maximizing seed dispersal from the surviving trees after fire by ensuring the survival of a sufficient number of "green islands" of seed trees in the forest."

26. line 79. Was this fire natural in origin or lighted by man? A little more context would be useful here, e.g. what might the natural fire regime be in this area? Are most fires that occur in the region, man-made in origin? Are there plans to increase prescribed burning, to reduce wildfire frequency?

ADDED: "Fire regime here is characterized mainly by late winter - early spring fires (cause of ignition: $96 \%$ anthropogenic; $4 \%$ natural). Surface fires usually start at the bottom of the valley and spread up to the top of the mountain, often originating crown fires in conifers due to the low moisture content of live foliage during the dormant season. Wildfires are small in size (average $=$ $8 \mathrm{ha}$ ); however, the $70 \%$ of the burnt area is due to sporadic but relatively large (>20 ha) wildfires. This fire regime is common to several inner alpine valleys (Moser et al., 2010; Zumbrunnen et al., 2011) and reflects the influence of fire suppression policies adopted throughout the alpine region (Ascoli et al. 2013; Pezzatti et al. 2013)."

27. line 87. It's not just the dryness but also presumably the fact that most woody plants are not actively growing in this season (and so have low moisture in their live fuels), that leads to an increase in fire frequency. Late winter / early spring is typical fire season in this kind of habitat. Here and elsewhere some wider context and commonalities from other flammable ecosystems around the world would be good, you could use general fire ecology references like e.g. Bond \& Wilgen 1996 or Whelan 1995.

ADDED, see previous point

28. line 89. 'Foehn' winds might need a reference to explain it.

\section{ADDED}

29. line 102. Arctostaphylos mis-spelt.

\section{EDITED}

30. line 105. 'Ladder' fuels needs a reference or explanation for the general reader.

EDITED line 105: provided fuel vertical continuity (i.e., "ladder fuel")

31. Similarly, 'spotting events' (line 107).

ADDED reference to line 107

32. line 109. Reference needed for Fire Weather Index.

ADDED

33. line 116. 'Standard post-fire practice in the area' would be better than 'consolidated post fire management practices'.

\section{EDITED}

34. line 120. More is needed here to satisfy the reader that salvage logging impacts on soils were minor. Was all felling by hand / chainsaw or were machines used? However, I think it would be fairer to say that your study is about a wildfire site that has been restored using standard local practice, rather than attempting to demonstrate that it is behaving 'as if' there had been no salvage logging.

EDITED: "Salvaging was carried out by a combination of chainsaw felling and cable logging. This should cause little impact to the soil (Dryness et al., 1957); however, since greater impacts are to be expected on disturbance legacies such as standing dead trees or woody debris, it is to be reminded that the present study will address a wildfire site that has been restored using standard local practice."

35. line 123. Figure 1 could be improved a lot. On the orientation inset map, it needs coast and national boundaries, and one or two large cities, to orientate the international reader. On the detailed map it needs the recording plots to be marked (or shown on a larger scale third map). 


\section{A NEW FIGURE WAS DRAWN USING THE REVIEWER'S SUGGESTIONS}

36. line 124. "sampling plots of radius $3 \mathrm{~m} 2$ " would be clearer. The letter ' $R$ ' can have many meanings.

\section{EDITED}

37. line 126. Why not simply 'intermediate' for moderate / high?

\section{EDITED throughout the paper}

38. line 131. You could discuss more fully the implications of having done a study in one year, five years after the fire.

ADDED (in Discussions): "There effects will likely continue to operate in the years following this study. Previous research showed that regeneration of Scots pine is a gradual process in disturbed forests of dry, inner-alpine valleys, taking up to 8-16 years after fire (Vacchiano et al., 2013), i.e., a longer window than in Mediterranean or Continental ecosystems (Bullock, 2009; Retana et al., 2012). After that time, the first post-disturbance cohort should reach sexual maturity (10 - 20 years in Scots pine: Vilà-Cabrera et al., 2011) and the regeneration process should therefore occur more rapidly, thanks to the ever decreasing distance from new seed trees."

39. line 136. This passage is not clear. Did you have plots that were close to each other but either side of the boundary of the canopy fire? How were you able to match these aspects if the plot locations were randomly selected? Simplest would be to give a figure showing the location of the recording areas.

EDITED: "Sampling locations were chosen randomly provided that the following criteria were met: (a) plots were close to each other (maximum distance between any two plots: $500 \mathrm{~m}$ ), so as to control for variability in macrotopography, but either side of the surface and crown fire perimeter; (b) plots must be placed within a pre-fire forest mask (source: Regione Autonoma Valle d'Aosta) in order to avoid sampling in areas not covered by forest even before the disturbance."

Moreover, plot locations were added in Figure 1.

40. line 155. 10-hour fuels etc is fire jargon which will be unfamiliar to the general reader; give reference or explain in the text. Or just drop the '10-hour', '100-hour' etc descriptions since you also give the diameters anyway.

EDITED: "Required inputs are fuel classes loads which includes: litter, dead woody fuels separated in diameter classes of $0-0.6 \mathrm{~cm}, 0.6-2.5 \mathrm{~cm}, 2.5-7.5 \mathrm{~cm}$, and $>7.5 \mathrm{~cm}$, corresponding respectively to 1 hour (-hr), 10-hr, 100-hr, 1000-hr timelag classes (Pyne et al. 1996), herbs, shrubs, and tree crown foliage and branches. Other inputs are percent canopy fuel consumption, moisture content of 10-hr and 1000-hr dead woody fuels, and of the soil, and soil texture."

41. line 161. Again, line intercept sampling is standard for downed woody fuels but you should give a reference for general reader.

\section{ADDED}

42. line 167. This seems like a high temperature use for drying fuels to assess moisture contents. Give a reference for use of this temperature. Also, did you check that fuels dried to constant weight? I would think 100 hour fuels would need longer.

EDITED to $90^{\circ} \mathrm{C}$. 100 -hr dead fuels loadings were assessed by line intersect sampling (see lines $160)$ and not dried in the oven (EDITED line 155)

43. line 188. Surely it would be better to estimate fire behaviour for the intermediate site also, using an intermediate value of crown fuel consumption and duff consumption.

ADDED: intermediated severity fire was simulated by using intermediate crown fuel consumption and complete duff consumption. Paragraph 2.3 was EDITED accordingly. Results were ADDED in the new Figure 2 and in the Results section, and discussed in Discussions.

44. line 195. Reference needed for the Carlo Erba analyser method.

ADDED 
45. line 219. You could insert "The medians of " regeneration and soil variables were compared... ADDED

46. line 227. It is confusing to use ' $p$ ' to mean 'the number of predictors' when often it means ' $p$ value'.

\section{EDITED: "PAR"}

47. line 226. But surely it would also be interesting to see if regeneration varied significantly between different categories of fire on your study site? Ideally you would investigate this in an analysis that included distance to seed tree as a covariate, so you separated the seedfall effect from the site characteristics effect.

ADDED (in methods): "Seedling density was compared across fire severity levels by ANCOVA, where distance from seed trees was used as a covariate in order to investigate the effects of site properties separately from the seedfall effect, which we presumed would affect regeneration. Treatments were compared by Tukey post-hoc test $(p=0.05)$, under a null hypothesis of no statistical difference."

ADDED (in Results): "Seedling density was higher in the moderate severity and intermediate severity plots; however, when distance from seed trees was included as a covariate, no differences could be detected among burned plots."

48. line 229. 27 variables, or even 18 (line 234) is a very large number when your sample size is only 20. I think your analysis would be more robust if you re-ran it with a smaller number of variables (say, five) selected on the basis of your prior knowledge as to what is likely to affect regeneration.

EDITED: the effective number of parameters included in the GLM was 6, following variable selection by correlation analysis and random forest. The methods and results sections were edited for better clarity.

49. line 229. I would include 'distance to seed trees' in all models (not subjecting it to any variable selection process), so as to investigate the effects of site properties separately from seed tree distance, which we already know will affect regeneration. Seed tree distance would be expected to have a non-linear relationship with seed fall (and therefore regeneration) (e.g. Greene \& Johnson 1996). [also reported for Table 4]

ADDED (in methods): "Distance from seed trees was included a priori in the GLM as either a linear or a quadratic term (e.g., Greene and Johnson 1996)".

ADDED (in results): "Deviance explained (i.e., 1 - residual deviance / null deviance) was almost unchanged when using a linear or quadratic term for seed tree distance as a predictor (i.e., $86.5 \%$ vs. $86.7 \%$, respectively); only results from the linear model are reported"

50. line 251-3. These results would be clearer in a table.

\section{TEXT REPLACED BY NEW TABLE 2.}

51. line 254. If this is fireline intensity, then it's per metre, not per metre squared.

NOT EDITED: in FOFEM fire intensity is calculated in $\mathrm{kW} / \mathrm{m} 2$ and is intended as the energy release from organic matter combustion per unit volume multiplied by the velocity at which the energy is moving (kW/m2), and not Byram's fireline intensity $(\mathrm{kW} / \mathrm{m} \mathrm{sec})$, as we defined in the introduction.

52. line 265. Remind the reader that the low percent cover of woody debris in the high intensity area is partly a result of salvage logging and associated activities.

ADDED.

53. line 300. One area that could be very important in affecting the patterns of seedlings found, but is not discussed at all, is seed and seedling predation. See e.g. Nystrand and Granstrom 2000.

ADDED (in Discussions): "On the other hand, due to the opportunistic nature of the study, we could not assess the influence of seed and seedling predation on regeneration abundance. Previous experiments (Castro et al., 1999; Nystrand and Granstrom, 2000) found that seed predation (e.g., by carabids, birds, and microtine rodents) could determine up to $96 \%$ recruitment 
failures, and seedling predation (e.g. by slugs) from 5 to $100 \%$ mortality. Furthermore, the intensity of predation can interact with disturbance legacies, e.g., residual vegetative cover (Castro et al., 2002) or coarse woody debris (Nystrand and Granstrom, 2000)."

54. line 313. Depth of burn needs a reference or definition in the text (e.g. Schimmel \& Granstrom 1996).

ADDED: "(i.e., the depth of the soil profile exposed after duff consumption)"

55. line 323. Use a more widely available reference to fire regimes in Scots pine e.g. Agee 1998 and/or a prescribed burning study in Scots pine forest showing high survival of canopy trees e.g. Hancock et al 2011.

ADDED

56. line 325. Are you not able to find out more about what salvage logging would have been done? e.g. by asking local foresters or officials who ordered the logging, or contractors who carried it out? Or by referring to best practice guides for salvage logging in the region?

ADDED: " Small, unlogged portions inside the high severity fire perimeter had no living trees, except for two patches of surviving trees ("green islands" sensu Ordóñez et al., 2005), probably due to a locally different fuel structure and hence local changes in fire behavior."

57. line 335. Small numbers of seeds will disperse much further than this under exceptional circumstances (e.g. Greene \& Johnson 1997). Studies such as this, and paleo-ecological studies of relatively rapid migration of treelines, show that the disperal of conifers can strongly affected by rare, longer distance events. So better phrasing would be"...23m from seed source, the region in which most seed rain falls".

58. exceptional circumstances (e.g., Greene and Johnson, 1996, 1997). Such rare, longer distance events can strongly affect the dispersal of conifers, but in our study they were not influential, due to the relatively short time elapsed since the disturbance."

59. line 403. Did you not do whorl counts - in which case you could give data on the size at a given age, rather than just size? In order to discuss relationships between height and growth rate, you need to know age.

EDITED: "sapling height, age, and yearly growth in the moderate severity fire were lower than in the intermediate severity fire (Table 3 ) "

60. line 405. Hence, the low seedling counts in the high intensity area may partly reflect the effects of salvage logging, which removed much of the woody debris. This could be brought out more clearly.

\section{ADDED}

61. p448. I think you mean 'leave' rather than 'release'.

\section{EDITED}

62. Table 2. This information would be clearer as a figure with depth vs temperature and time for each severity.

THE TABLE HAS BEEN REPLACED BY A FIGURE. Numeration of Tables and Figures has been edited accordingly.

63. Table 3. The data from the unburnt areas should be included here. Also, why are there no ranges for the seed trees? You could also present the mean and range for seedling ages for each site type.

ADDED 


\section{Fire severity, residuals and soil legacies affect regeneration of Scots pine in the Southern Alps}

\section{Highlights}

We analyzed fire legacies and regeneration in a Scots pine forest of the inner Alps.

Legacies included surviving canopy, soil legacies and coarse woody residuals.

Fire simulations showed critical heating of the topsoil under high severity fire.

Fire decreased soil aggregate stability, organic matter and exchangeable cations.

Pine seedlings established on poor, eroded soils, and were facilitated by residuals. 
Giorgio VACCHIANO ${ }^{*}$, Silvia STANCHI ${ }^{a}$, Giulia MARINARI ${ }^{a}$, Davide ASCOLI ${ }^{a}$, Ermanno ZANINI ${ }^{a}$, Renzo MOTTA ${ }^{a}$

${ }^{a}$ Dipartimento di Scienze Agrarie, Forestali e Alimentari, Università degli Studi di Torino. Via da Vinci 44, 10095 Grugliasco (TO), Italy.

* corresponding author. Email giorgio.vacchiano@gmail.com, tel +39-0116705536, fax +39-0116705556

\section{Fire severity, residuals and soil legacies affect regeneration of Scots pine in the Southern Alps}




\title{
Fire severity, residuals and soil legacies affect regeneration of Scots pine in the Southern Alps
}

\begin{abstract}
Regeneration of non fire-adapted conifers following crown fires on the European Alps is often delayed or unsuccessful. Fire may limit establishment by eliminating seed trees, altering soil properties, or modifying microsite and soil conditions via disturbance legacies. However, the effect of soil legacies on post-fire establishment has rarely been discussed. We analyzed the abundance of Scots pine regeneration in a 257 ha wildfire in an inner-alpine forest. Our aims were (1) to model fire intensity at the soil surface and topsoil heating along a gradient of increasing fire severities; (2) to assess the differences in soil properties along the fire severity gradient; (3) to model the effect of disturbance and soil legacies on the density of pine seedlings. We reconstructed fire behavior and soil heating with the First Order Fire Effects Model (FOFEM), tested the effect of fire severity on soils by nonparametric distributional tests, and modeled seedling density as a function of site, disturbance and soil legacies by fitting a GLM following a variable selection procedure. Topsoil heating differed markedly between the moderate and high severity fires, reaching temperatures high enough to strongly and permanently alter soil properties only in the latter. High fire severity resulted in decreased soil consistency and wet aggregate stability. Burned soils had lower organic matter and cations than those unburned. Pine seedlings favored low-fertility, eroded, and chemically poor sites. Establishment was facilitated by the presence of coarse woody debris, but hampered by increasing distance from the seed source. These results suggest that in dry, inner-alpine valleys, fire residuals and soil legacies interact in determining the success of Scots pine re-establishment. High severity fire can promote favorable soil conditions, but distance from the seed source and high evaporation rates of bare soils must be mitigated in order to ensure a successful restoration.
\end{abstract}

Keywords: Crown fire; Disturbance ecology; FOFEM; Pinus sylvestris L.; Soil aggregate stability; Soil quality 


\section{Introduction}

Scots pine (Pinus sylvestris L.) is the most widespread coniferous species in Europe, and the most widespread pinein the world (Mirov, 1967). At the dry, southern edge of its distribution, it is currently facing complex dynamics of decline and succession, which result from the interaction between environmental change, land use changes, and increased susceptibility to disturbance (Gimmi et al., 2010), including fire.

Fire regimes in Scots pine were described as moderate-severity (Agee, 1998). The species has been observed to resist multiple fires (Stouranet et al., 2013), and to regenerate successfully in low-frequency fire regimes, in both boreal and continental European forests (Fernandes et al., 2008; Hille, 2006; Niklasson et al., 2010), e.g., also following the application of prescribed burning (Hancock et al., 2009; Hille and den Ouden, 2004).

However, regeneration of Scots pine following high severity crown fires on the European Alps and in the Mediterranean mountains was often delayed or unsuccessful (Moser et al., 2010; Rodrigo et al., 2004). Many limiting factors have been identified, including limited seed dispersal distance (Vilà-Cabrera et al., 2011), short persistence of viable seeds in the soil (Nyman, 1963), competition or allelopathy by herbs or sprouters (Hille and den Ouden, 2004), loss of micorrhiza associated to pine regeneration (Bastias et al., 2006; Curlevsky et al., 2011; Kipfer et al., 2011), and unfavorable water balance due to high soil evaporation (Castro et al., 2004; Vacchiano et al., 2013). Most of these factors depend on fire type (e.g., crown vs. surface-fire), fire intensity, (i.e., the energy release from organic matter combustion per unit volume, times the velocity at which the energy is moving $\left[\mathrm{kW} \mathrm{m}^{-2}\right]$, and fire severity, i.e., tree mortality and soil organic layer consumed (Keeley, 2009).

Fire legacies are living organisms, e.g., seed trees ("residuals" sensu Pickett and White, 1985), dead organic matter (e.g., logs), and physical structures (e.g., exposures of mineral soil) that remain after the disturbance (White and Jentsch, 2004). Legacies play a key role in facilitating regeneration establishment, increasing plant growth, and promoting ecosystem functioning, e.g., in terms of nutrient availability, diversity and abundance of microsites, soil respiration and biotic community functioning, in many Mediterranean, temperate, boreal and tropical forest ecosystems throughout the world (e.g., Beard et al., 2005; Castro et al., 2012; Griffin and Turner, 2012; Marañón-Jiménez et al., 2013a; Marañón-Jiménez and Castro, 2013; Peterson and Leach, 2008).

Similarly, soil legacies are the degree to which soil properties and functions are modified following a disturbance (Baer et al., 2012). Fire can affect a wide range of soil properties 
both at the surface and along the profile (Bento-Gonçalves et al. 2012), such as organic matter (OM) pools (González-Pérez et al., 2004), aggregate stability (Mataix-Solera et al., 2011), nutrient content (Neary et al., 1999), and water repellency (Doerr et al., 2010). many of these issues are applicable quite widely around the world (e.g., Bogorodskaya et al., 2011; Covington and Sackett, 1990; Granged et al., 2011; Jordán et al., 2011; Mallik et al., 1984; Mills and Fey, 2004; Wan et al., 2001). The magnitude and temporal extent of fire-induced changes in soil properties is related to the duration and depth of soil heating (Table 1). In order to sustain the flow of ecosystem services provided by the mountain forest, e.g., protection from gravitational hazards and recreation, rapid restoration of forest cover is often desired following catastrophic disturbances (Dorren et al., 2004). However, when temperatures able to alter soil properties are reached (e.g., $60^{\circ} \mathrm{C}$ for the destruction of the microbial pool, and $220^{\circ} \mathrm{C}$ for incipient structural degradation), soil resilience, i.e., the capability to recover after severe stress (Seybold et al., 1999), may be compromised (Certini, 2005), potentially delaying or preventing the establishment of tree regeneration.

Both disturbance and soil legacies are influenced by fire severity, and can alter the microsites available for plant regeneration (Leverkus et al., 2012; Marañón-Jiménez et al., 2013b; Marzano et al., 2013; Schimmel and Granstrom, 1996). However, the role of soil legacies on post-fire regeneration (e.g., Giardina and Rhoades, 2001; Lynham et al., 1998) has not been adequately enquired, particularly for Scots pine. In the view of expected increases in fire activity due to global changes, particularly in the Alpine region (e.g., Ascoli et al., 2013; Moser et al., 2010), a better knowledge of Scots pine regeneration dynamics after fire is needed to plan for a successful post-fire restoration.

We analyzed pine regeneration five years since a stand-replacing fire in a dry, inner-alpine Scots pine forest. Our aims were: (1) to model fire intensity at the soil surface and the amount and duration of soil heating along a gradient of increasing fire severity; (2) to assess the differences in chemical and physical soil properties of along the fire severity gradient; and (3) to assess the effect of increasing fire severity on pine regeneration by modeling the influence of disturbance residuals and soil legacies on the density of pine seedlings.

\section{Materials and Methods}

\subsection{Study area}

The study area is located in central Valle d'Aosta, an inner valley of the south-eastern Alps. Fire regime here is characterized mainly by late winter - early spring fires (cause of ignition: 96\% anthropogenic; $4 \%$ natural). Surface fires usually start at the bottom of the valley and 
spread up to the top of the mountain, often originating crown fires in conifers due to the low moisture content of live foliage during the dormant season. Wildfires are small in size (average $=8 \mathrm{ha}$ ); however, the $70 \%$ of the burnt area is due to sporadic but relatively large (>20 ha) wildfires. This fire regime is common to several inner alpine valleys (Moser et al., 2010; Zumbrunnen et al., 2011) and reflects the influence of fire suppression policies adopted throughout the alpine region (Ascoli et al. 2013; Pezzatti et al. 2013).

The study site is a human-caused wildfire that occurred on $12^{\text {th }}$ March 2005 in the

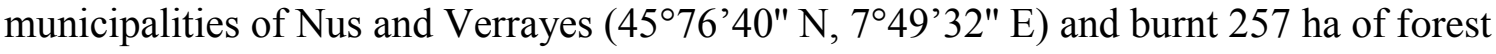
vegetation. The fire perimeter lies on a moderately steep (33 to 45\%), southerly-exposed slope, at elevations ranging between 1190 and $1870 \mathrm{~m}$ a.s.l. The bedrock consists of colluvial sediments rich in ophiolite and schist. Soils are mostly Entisols (Stanchi et al., 2013a) with a sandy texture, moderate rock fragment content (3-15\%), and a typical sequence of O-A-C horizons. No diagnostic horizons are detectable.

Mean annual temperature is $5.6^{\circ} \mathrm{C}$, and mean annual precipitation is $750 \mathrm{~mm}$ (Marzano et al., 2013). February is the driest month, coinciding with the main peak of the fire season. The south-facing slopes of central Valle d'Aosta experience a high fire risk (Cesti and Cerise, 1992). Additionally, dry and warm katabatic winds blowing across the region (Wastl et al., 2013) may decrease air and fuel moisture, increase winter air temperatures, and sustain the spread of ensuing flame fronts.

The fire burned through a mature, even-aged conifer forest, dominated by Scots pine (77\% basal area on average) with mixed larch (Larix decidua Mill.: 15\%) and spruce (Picea abies Karst.: 7\%), and sporadic broadleaves (1\%), such as downy oak (Quercus pubescens Willd.), aspen (Populus tremula L.), birch (Betula pendula Roth.) and ash (Fraxinus excelsior L.). Pre-fire stands had 1443 trees per hectare on average (standard deviation: 658.9), a quadratic mean diameter of $17.5(1.75) \mathrm{cm}$, a basal area of $32.7(10.45) \mathrm{m}^{2} \mathrm{ha}^{-1}$, and a dominant height of about $15 \mathrm{~m}$ (data from a regional forest inventory pre-dating the fire, 4 plots within the fire perimeter: Figure 1). Approximate stand age was 60 years, with sporadic older trees (maximum age: 122 years).

Surface fuels were composed by a $4-\mathrm{cm}$ thick litter of needles, oak leaves and fine $(<0.6 \mathrm{~cm})$ woody debris, some dead coarse woody, and a live layer of small shrubs (Arctostaphylos uvaursi (L.) Spreng.) and grass (Bromus erectus Huds.), which carried surface fire spread. A patchy understory of elevated shrubs (e.g., Juniperus communis L., Rubus idaeus L.) and the lower pine branches provided fuel vertical continuity (i.e., "ladder fuel") for crown fire initiation. The fire started at the urban interface at $1190 \mathrm{~m}$ a.s.l. and spread up to $1870 \mathrm{~m}$ a.s.l. 
as a slope and wind-driven fire. Several spotting events (Albini et al., 2012) were observed. At the time of maximum spread, foehn winds were blowing at an average speed of $41 \mathrm{~km} \mathrm{~h}^{-1}$, with gusts of $60 \mathrm{~km} \mathrm{~h}^{-1}$ (Valese, 2008); air moisture was reduced to 8\%, while the Fire Weather Index (i.e., a weather-based metric of the potential intensity of a spreading fire: van Wagner, 1987) was 79.6; moisture content of dead woody fuels $(0.6-2.5 \mathrm{~cm}$ ) was $12 \%$ (Cesti, 2011). Crown fire behavior occurred on $62 \%$ of the burned area (Figure 1), while the rest experienced surface fire displaying a flank of back fire behavior (source: Corpo Forestale Regionale Valle d'Aosta). The fire resulted in a mixed severity pattern: from high severity in crown fire areas, to moderate severity after flank-back fire.

The fire was extinguished after 9 days. In the year 2009, the area affected by crown fire was salvage logged according to standard post-fire practice in the area (Marzano et al., 2013). All trees within the crown fire perimeter, either standing or lying on the ground, were debranched and harvested. Branches were cut to $<1 \mathrm{~m}$ length and piled in the vicinity of boulders, stumps, or mounds. Salvaging was carried out by a combination of chainsaw felling and cable logging. This should cause little impact to the soil (Dryness et al., 1957); however, since greater impacts are to be expected on disturbance legacies such as standing dead trees or woody debris, it is to be reminded that the present study will address a wildfire site that has been restored using standard local practice.

\subsection{Sampling design}

After preliminary survey of the fire perimeter (Figure 1), we established five circular sampling plots of radius $3 \mathrm{~m}$ in each of the following four fire severity levels: unburned, surface flank-back fire (moderate severity), transition sites between crown and surface fire (intermediate severity), and crown fire (high severity). Sampling locations were chosen randomly provided that the following criteria were met: (a) plots were close to each other (maximum distance between any two plots: $500 \mathrm{~m}$ ), so as to control for variability in macrotopography, but either side of the surface and crown fire perimeter; (b) plots must be placed within a pre-fire forest mask (source: Regione Autonoma Valle d'Aosta) in order to avoid sampling in areas not covered by forest even before the disturbance.

Field sampling was carried out in summer 2010, i.e., 5 years after fire. Our study was opportunistic in nature, i.e., pre-fire data on soils and stand structure were not available. In order to rule out possible pre-fire differences in stand structure, we sampled, averaged, and compared the number and root collar diameter ( $\mathrm{rcd}$ ) of live and dead mature trees and of all stumps in each plot (only individuals with $\mathrm{rcd}>7.5 \mathrm{~cm}$ ). 
In each plot we recorded the density, rcd, age by whorl count, whorl length, and height of all Scots pine seedlings. Seedlings were searched visually by stooping to the ground from inside each plot for at least 30 minutes. Areas around and below shrubs and woody debris were searched as well, in order to minimize detection errors (Hancock et al., 2009).

Disturbance legacies were sampled by measuring the canopy cover of trees surviving the fire, and percent soil cover by shrubs, herbs, rocks and bare ground, and coarse woody debris (all by visual assessment). In order to measure soil legacies, at the center of each plot we took four subsamples of the topsoil at a depth of 0 to $5 \mathrm{~cm}$ (A horizon) below the litter (Oi) and duff (Oe+Oa) layers, that were discarded. Total sampled soil was about $3 \mathrm{~kg}$ per plot; subsamples were mixed for subsequent analyses. Rock fragment content (\% volume) was visually assessed in the field; other soil variables were computed in the lab (see paragraph 2.4).

\subsection{Fire simulation}

We simulated fire behavior and severity using the First Order Fire Effects Model (FOFEM) version 6 (Lutes et al., 2013), that provides quantitative predictions of the intensity of the igniting surface fire, fuel consumption, and associated soil heating (peak temperatures and duration). Required inputs are fuel classes loads which includes: litter, dead woody fuels separated in diameter classes of 0-0.6 cm, 0.6-2.5 cm, 2.5-7.5 cm, and $>7.5 \mathrm{~cm}$, corresponding respectively to 1 hour (-hr), 10-hr, 100-hr, 1000-hr timelag classes (Pyne et al., 1996), herbs, shrubs, and tree crown foliage and branches. Other inputs are percent canopy fuel consumption, moisture content of 10-hr and 1000-hr dead woody fuels, and of the soil, and soil texture.

Fuel inputs were computed by a combination of destructive and non-destructive sampling. In four random locations of the unburned forest, we measured the volume of 100-hr and 1000-hr dead woody fuels by line intercept sampling (Warren and Olsen, 1964) along three transects arranged in a triangular plot (10 m per side). Fuel loadings were obtained by applying a specific gravity of $412 \mathrm{~kg} \mathrm{~m}^{-3}$ (Ottmar et al., 2007). Every $3 \mathrm{~m}$ along the transects, we collected (a) cones and 10-hr dead woody fuels in 100x100 cm quadrats, (b) litter (Oi), fermentation layer (Oe), 1-hr dead woody fuels and herbs in 40x40 cm quadrats, and (c) the humic layer (Oa) using a hollow metal sampling cylinder (diameter $=10 \mathrm{~cm}$, height $=2 \mathrm{~cm}$ ). All samples were oven dried to constant weight $\left(90^{\circ} \mathrm{C}\right.$ for $48-72$ hours), sieved, and weighed. The dry weight of duff $(\mathrm{Oe}+\mathrm{Oa})$ was used to compute duff bulk density (i.e., $0.177 \mathrm{~g} \mathrm{~cm}^{-3}$, standard error $0.006 \mathrm{~g} \mathrm{~cm}^{-3}$ ) and loading per hectare. Cone loadings were added to $100-\mathrm{hr}$ 
dead woody fuels. Tree crown foliage mass was allometrically determined as a function of the diameter at breast height ( $\mathrm{dbh}$ ) of each living tree within a concentric fuel survey plot $($ radius $=10 \mathrm{~m})($ Riaño et al., 2004). Branch mass was computed as $0.7 *$ foliage mass (Vanninen and Mäkelä, 2005). All fuel loadings were averaged across the four plots and entered in FOFEM.

We set the additional inputs required by FOFEM as follows: soil texture = "coarse-loamy", i.e., $>15 \%$ fine sand or coarser, including fragments up to $7.5 \mathrm{~cm}$ in diameter, and $<18 \%$ clay in the fine-earth fraction; moisture content of the $0.6-2.5 \mathrm{~cm}$ dead woody fuel class $=$ 12\%, after field measurements carried out during wildfire propagation (Cesti, 2011); moisture of duff, 1000-hr dead woody fuels and soil $=40 \%, 15 \%$ and $10 \%$, respectively, after the "dry" moisture scenario included in FOFEM (Lutes, 2013).

For the moderate, intermediate, and high fire severity levels, we simulated: (a) the intensity of the igniting surface fire, by setting crown fuel consumption to $0 \%$ ì, $50 \%$ and $100 \%$, respectively; (b) soil peak temperatures and the duration of soil heating at the soil surface and up to $10 \mathrm{~cm}$ in the soil, by instructing FOFEM to use the Duff Fire Model for the moderate severity fire, and the Zero Duff Model for the intermediate and high severity fire. The Zero Duff Model computes soil heating by assuming complete duff consumption, while the Duff Fire Model computes it as a function of duff consumed during a smoldering combustion in a given moisture scenario and soil texture (Lutes, 2013).

\subsection{Soil analyses}

Soil samples were oven dried and sieved. In the lab, we carried out the following analyses:

(1) soil pH was determined potentiometrically (Società Italiana di Scienza del Suolo, 2000);

(2) total organic carbon (TOC) and total nitrogen content (TN) were determined by dry combustion with Carlo Erba elemental analyzer (Fisons Instruments NA1500, Dearborn, MI); (3) cation exchange capacity (CEC) was measured with the $\mathrm{BaCl}_{2}$-triethanolamine method at pH 8.1 (Rhoades, 1982), and exchangeable cations were subsequently determined by AAS (atomic absorption spectrophotometer); (4) soil texture (particle size: sand 0.6-0.06 mm, silt 0.002-0.06 mm, clay $<0.002 \mathrm{~mm}$ ) was determined by the pipette method after dispersion with Na-hexametaphosphate (Gee and Bauder, 1986); (5) wet aggregate stability (WAS) was determined by wet sieving using different sieving times $(5,10,15,20,40,60 \mathrm{~min})$ (Zanini et al., 1998; Stanchi et al., 2013b). Three parameters of fitted breakdown curves were considered: incipient failure of the aggregates when water-saturated (WAS a), maximum estimated abrasion loss (WAS b), and the velocity of aggregates breackdown (WAS c); (6) 
the Atterberg liquid limit (LL) was determined with a semi-automatic cone penetrometer and the plastic limit (PL) by the thread rolling method (Società Italiana di Scienza del Suolo, 2000). Atterberg limits represent the gravimetric water content (\%) needed for the transition of a soil sample from the semisolid to plastic state (PL), and from the plastic to the liquid state (LL). Liquid and plastic limits are related to soil structure and organic matter content (Dexter et al., 2008; Keller and Dexter, 2012), and have been used as indicators of soil aggregation and vulnerability in a watershed that includes the study area (Stanchi et al., 2008a; 2012; 2013b).

All analyses and physical determinations were performed in duplicate, and then averaged. Regeneration and soil data are available at the PANGAEA repository (http://doi.pangaea.de/10.1594/PANGAEA.818321).

\subsection{Statistical analysis}

The medians of soil variables were compared across fire severity levels by means of nonparametric Kruskal-Wallis test with Tukey's post-hoc test $(\mathrm{p}=0.05)$, under a null hypothesis of no statistical difference. Seedling density was compared across fire severity levels by ANCOVA, where distance from seed trees was used as a covariate in order to investigate the effects of site properties separately from the seedfall effect, which we presumed would affect regeneration. Treatments were compared by Tukey post-hoc test $(\mathrm{p}=0.05)$, under a null hypothesis of no statistical difference.

To describe the joint effect of site, disturbance and soil legacies on pine recruitment, we fitted a General Linear Model (GLM) to pine seedling density, pooling data from all burned plots (i.e., excluding unburned plots). We positively tested the raw response variable for overdispersion by computing its deviance and referring this to a Chi-square distribution with (no. observations - 1) degrees of freedom ( $\mathrm{p}<0.001)$. Therefore, we fitted the GLM using a negative binomial distribution.

We did not include fire severity level as a categorical predictor, but rather assessed the effects of the quantitative variables that it would directly affect. Potential predictors (PRED) included distance from residual seed trees, canopy cover of surviving trees, percent soil cover by class, and all soil variables described above, for a total of 27 variables. All predictors were standardized.

Due to the high dimensionality of our dataset (predictors > observations), we operated the following variable selection process: (1) we retained only one predictor from any pair of 
variables showing a marginal correlation coefficient (Pearson's R) $>|0.70|$; (2) we entered the selected predictors $(\mathrm{PRED}=18)$ in a random forest regression. Random forests (Breiman, 2001) combine many binary decision trees built by using bootstrap samples and choosing randomly at each node a subset of explanatory variables. Random forests can successfully be applied to dataset with highly correlated variables (Genuer et al., 2010). We used the randomForest package (Liaw and Wiener, 2012) for the R framework, version 2.15.2 (R Core Team, 2012), with the following settings: number of trees to build $=9999$, minimum size of terminal nodes $=5$, size of predictor subset $=6$ (i.e., PRED/3). The independent variable was the abundance of pine seedlings; however, the analysis was carried only for variable selection purposes. To do so, we computed the permutation importance index (incMSE) associated to each predictor, i.e., the percent increase in mean square error of a tree in the forest when the observed values of the predictor are randomly permuted. Finally, we used predictors with incMSE >0 to fit a GLM of pine seedling abundance (maximum iterations: 49, distribution: negative binomial). Distance from seed trees was included $a$ priori in the GLM as either a linear or a quadratic term (e.g., Greene and Johnson 1996). Effect size and direction of each predictor were assessed by standardized regression coefficients (beta).

\section{Results}

\subsection{Fire simulation}

Using fuel loadings computed from field sampling (Table 2), FOFEM produced a maximum surface fire intensity of 241,420 and $522 \mathrm{~kW} \mathrm{~m}^{-2}$ in the moderate, intermediate, and high severity fire, respectively. The peak temperature at the mineral soil surface was $43^{\circ} \mathrm{C}, 340^{\circ} \mathrm{C}$, and $428^{\circ} \mathrm{C}$, respectively, but dropped sharply with increasing soil depth (Figure 2). In the moderate severity fire, modeled temperature never exceeded $60^{\circ} \mathrm{C}$ throughout the topsoil. In the intermediate and high severity fires, modeled temperatures exceeded $60^{\circ} \mathrm{C}$ throughout the topsoil for more than five hours, and $220^{\circ} \mathrm{C}$ for about three hours in the top 2 or $3 \mathrm{~cm}$, respectively.

\subsection{Disturbance legacies}

Pre-fire stand density was similar under all fire severity levels (Table 3). However, pre-fire mean tree diameter was higher under increasing fire severities. This difference might have been conducive to a change in fire behavior, influencing surface and crown fuel continuity, but should not be influential on post-fire soil and regeneration dynamics. Herbaceous soil cover was highly variable across fire severity levels (10 to $92 \%$ ); shrub cover was generally 
low, but reached a maximum of 50\% in the high severity fire (Table 3). Coarse woody debris cover was higher in the moderate severity fire (40\%); the low percent cover of woody debris in the high intensity area was partly a result of salvage logging and associated activities. Rock/bare soil cover was higher in the high severity fire (28\%). Distance from the seed trees ranged from 0 (in unburned and moderate severity fires) to $26 \mathrm{~m}$ (high severity fire).

\subsection{Soil legacies}

Pre-fire soil conditions were unknown. However, topographic variables (elevation, slope, and aspect) and stand density exhibited a comparable range across fire severity levels (Table 3), therefore we could rule out bias due to such effects. Moreover, we don't expect that the scarce vegetation which has developed in the subsequent five years may have significantly altered soil variables.

All soil samples had $>50 \%$ sand, with very low amounts of clay. $\mathrm{pH}$ ranged between 7 and 8 (i.e., neutral to alkaline), with the cation exchange complex dominated by $\mathrm{Ca}$. TOC and TN ranged from $3 \%$ to $9 \%$ and from $0.1 \%$ to $0.5 \%$, respectively, and the $\mathrm{C} / \mathrm{N}$ ratio ranged from 17 to 35 . Most soil variables did not differ significantly under variable fire severity levels (Figure 3). However, the following trends were detected with increasing fire severity: (A) significantly lower sand and higher silt content; (B) a decrease of Atterberg's limits (LL, PL), and a significantly higher and faster loss of soil aggregates (WAS a+b and WAS c, respectively); (C) a highly significant reduction of exchangeable $K(\mathrm{p}<0.001)$, a reduction of exchangeable $\mathrm{Mg}$ and $\mathrm{CEC}$, and an increase in $\mathrm{pH}$; (D) a reduction of organic $\mathrm{N}$ and a significant increase in the $\mathrm{C} / \mathrm{N}$ ratio under all fire severities compared to unburned plots.

\subsection{Pine regeneration}

Five years after the fire, a total of 219 seedlings could be found at the sites. Scots pine accounted for $33 \%$ of the total abundance. Other species included aspen (32\%), downy oak (17\%), birch (9\%) and sporadic larch, ash, and willow (Salix caprea L.). Most broadleaves regenerated by shoot or root sprouting, and were merged in shrub cover in subsequent analyses. All pines were between 1 and 4 years old. No seedlings were found in unburned plots. In burned areas, the frequency of pine seedlings averaged 4.9 individuals per plot, corresponding to a density of $1733 \mathrm{ha}^{-1}$. Seedling density was higher in the moderate severity and intermediate severity plots; however, when distance from seed trees was included as a covariate, no differences could be detected among burned plots. On the contrary, mean height, 
total age, and mean whorl length of pine seedlings increased with increasing fire severity (Table 3).

After variable reduction by correlation analysis $(\mathrm{R}<|0.70|)$ and random forests (permutation importance $>0$ : Figure 4), five predictors in addition to distance from seed trees were entered into the GLM of seedling density. Deviance explained (i.e., 1 - residual deviance / null deviance) was almost unchanged when using a linear or quadratic term for seed tree distance as a predictor (i.e., $86.5 \%$ vs. $86.7 \%$, respectively); only results from the linear model are reported. Median bias (predicted - observed seedling density) was -0.19; residual plots were immune from heteroschedasticity or unaccounted trends. Among significant $(p<0.10)$ model predictors (Table 4), seedling density was negatively affected by distance from the seed trees (beta $=-2.23)$, clay content $(-0.90)$ and $\mathrm{K}$ saturation $(-0.94)$, and positively by CWD cover $(+0.75)$ and the $\mathrm{C} / \mathrm{N}$ ratio $(+0.79)$.

\section{Discussion}

\subsection{Fire simulation}

FOFEM allowed us to characterize quantitatively fire disturbance and support the interpretation of fire effects on post-fire residuals, disturbance and soil legacies, and Scots pine regeneration. The simulation of moderate fire severity resulted in a negligible soil heating even at the soil surface, as a likely consequence of the insulation properties of the unburned duff (Valette et al. 1994). Simulated surface fire intensity and peak temperature in the soil increased markedly under intermediate and high fire severity, i.e., when complete duff consumption was imposed. During crown fires in pine forests, canopy fuel combustion is triggered by high consumption of understory and surface fuels, which results in high surface fire intensity (Van Wagner, 1977). Moreover, depth of burn in the forest floor layer (i.e., the depth of the soil profile exposed after duff consumption) can reach $4 \mathrm{~cm}$ (Stocks et al., 2004), exposing mineral soil to the aboveground combustion. However, even under a high severity fire, soil heating decresed markedly at incresing depth, likely due to thermal insulation provided by the upper soil layers (DeBano, 1991; Hartford and Frandsen, 1992).

\subsection{Disturbance legacies}

Our study addressed three different types of fire legacies: surviving canopy trees, coarse woody debris on the ground, and exposed mineral soil. The amount and quality of legacies depend on both pre-fire condition and fire behavior (Foster et al., 1998). 
Surviving canopy cover is strictly dependent on fire behavior and species resistance. Scots pine is moderately resistant to surface fires (Agee, 1998; Hancock et al., 2011), which allowed the survival of most of the stand under moderate fire severity (mean residual canopy cover $=85 \%$, Table 3 ). We were not able to assess post-fire mortality under high fire severity due to the occurrence of salvage logging. Small, unlogged portions inside the high severity fire perimeter had no living trees, except for two patches of surviving trees ("green islands" sensu Ordóñez et al., 2005), probably due to a locally different fuel structure and hence local changes in fire behavior. By applying a published fire mortality model (Fernandes et al., 2008) using the fire intensity simulated for the high severity level, we obtain a 100\% canopy mortality (computed on model trees with $\mathrm{dbh}=15 \mathrm{~cm}$, height $=8 \mathrm{~m}$, and crown length $=6.5$ $\mathrm{m})$.

Since Scots pine is not a serotinous species (i.e., ones whose cones open when stimulated by heating), and the seeds stored in the soil are not resistant to heating by fire (Habrouk et al., 1999), canopy removals also affected post-fire seed dispersal. Sites burned by high severity fire were, on average, $23 \mathrm{~m}$ from the seed source, i.e., at the limit of the region in which most seed rain falls (Vilà-Cabrera et al., 2011: 50\% of seedlings within the first $10 \mathrm{~m}$, and $90 \%$ in the first $25 \mathrm{~m}$ from the seed source). Small numbers of seeds will disperse much further than this under exceptional circumstances (e.g., Greene and Johnson, 1996, 1997). Such rare, longer distance events can strongly affect the dispersal of conifers, but in our study they were not influential, due to the relatively short time elapsed since the disturbance.

The amount of coarse woody debris was lower under the moderate severity fire, where tree mortality was negligible, and higher under the intermediate severity, as a likely result of higher canopy mortality. Accordingly, the area burned by high severity fire should show even higher amounts of debris (Ascoli et al., 2013), but salvage logging removed most of the logs and snags, releasing only the smaller slash.

Finally, bare soil was more exposed after the high severity fire, likely due to higher fire intensities and harsher conditions for plant establishment after the disturbance. Under the intermediate severity fire, with abundant light and less intense disturbance, the herbaceous community recovered more quickly, so that the amount of exposed soil was minimal (Table $3)$.

\subsection{Soil legacies}

High, intermediate, and moderate fire severity differed for (a) residual canopy cover of surviving trees, (b) simulated surface fire intensity, and (c) simulated peak temperatures and 
duration of topsoil heating. All these elements contribute to determine differences in soil properties. Changes in the mineral topsoil following moderate severity fire were negligible (similarly to Marozas et al., 2013). However, a significant effect of increasing fire severity was detectable for a limited subset of soil variables. We explain this by the fact that simulated temperatures decreased sharply with soil depth: even under a high severity fire, only the upmost $3 \mathrm{~cm}$ exceeded $220^{\circ} \mathrm{C}$, i.e., a threshold associated with the degradation of soil organic matter and structural stability (Neary et al., 1999).

Severely burned areas are generally more susceptible to erosion of fine particles (Shakesby, 2011). However, we measured a higher content of silt and clay fractions under high fire severities (Figure 3A). As we did not remove organic cements during texture determination (Stanchi et al., 2008b), the enrichment in silt-sized classes might derive from the formation of relatively stable aggregates from the fine silt and clay fraction following exposure to high temperatures (Mataix-Solera et al., 2011).

High severity fire resulted in higher and quicker loss of soil aggregate and in the reduction of Atterberg limits (Figure 3B), which is consistent with previous research (w.g., Llovet et al., 2009; Úbeda et al., 2005). This can be a consequence of the deterioration of organic matter, and/or of increased erosion by surface runoff (Mataix-Solera et al., 2011). Reductions of aggregate stability in pine-dominated forest soils were observed after a minimum of one year (Martín et al., 2011) to a maximum of 12 (Kavdır et al., 2005) or even 19 years (MataixSolera et al., 2008) after the fire, depending on the course of post-fire vegetation recovery (Pérez-Cabello et al., 2010). Such time span includes the time elapsed in our study since the fire disturbance (i.e., five years).

Exchangeable $\mathrm{K}$ and $\mathrm{Mg}$ were reduced by high-severity fire (Figure 3C), as a result of volatilization during combustion (threshold temperatures of $1107^{\circ} \mathrm{C}$ and $760^{\circ} \mathrm{C}$ ) (Weast, 1988), and subsequent erosion and leaching following the initial "nutrient flush" in the ash layer (Gómez-Rey et al., 2013; Kutiel and Naveh, 1987).

The decrease of exchangeable cations and CEC can also be related to the loss of organic matter following high severity fire (Mangas et al., 1992). In fact, moderate and intermediate fire severities resulted in increased TOC and $\mathrm{C} / \mathrm{N}$ ratio (Figure 3D), which is consistent with most findings in the literature (Certini et al., 2011), and is attributable to the incomplete fuel consumption and to post-fire inputs of partially burnt plant materials, that are not easily decomposed. Under high severity fire, both TOC and TN decreased. This is attributable to the total consumption of live, dead, and duff fuels, to the heating of the topsoil to temperatures lethal to the soil microbial pool $\left(>60^{\circ} \mathrm{C}\right.$ ) (Figure 2), and of the upper $3 \mathrm{~cm}$ to temperatures 
responsible for direct $\mathrm{OM}$ degradation, both chemically $\left(>200^{\circ} \mathrm{C}\right.$ for Nitrogen to be lost: Chandler et al., 1983) and structurally $\left(>220^{\circ} \mathrm{C}\right)$.

\subsection{Pine regeneration}

Post-fire regeneration of obligate seeders is often described as a function of fire severity and disturbance legacies, i.e., residual canopy cover, competition by vegetation, exposed mineral soil, and distance form the surviving seed trees (Ascoli et al., 2013; Jayen et al., 2006; Vacchiano et al., 2013). We observed the following effects: (1) no regeneration was observed below the unburned, mature pine canopy. Moreover, sapling height, age, and yearly growth in the moderate severity fire were lower than in the intermediate severity fire (Table 3), confirming the negative effect of low light on seed germination and seedling growth, as was expected for a light-demanding species (Hille and den Ouden, 2004); (2) coarse woody debris facilitated seed establishment and survival (Table 4). In Mediterranean and inner-alpine ecosystems, the main abiotic factor constraining establishment of Scots pine is summer drought (Barbeito et al., 2009; Castro et al., 2004; Matías et al., 2011; Vacchiano et al., 2013). In such conditions, deadwood on the ground has the ability to mitigate excessive solar radiation and soil moisture losses (Castro et al., 2011; Jayen et al., 2006; Marañón-Jiménez et al., 2013; Marzano et al., 2013). On the other hand, the low seedling counts in the high intensity area may partly reflect the effects of salvage logging, which removed much of the woody debris; (3) distance from the seed source was the most important predictor of seedling abundance, so that there was almost no regeneration following high severity fire, that were located at a limiting distance for the species' seed dispersal capabilities (Vilà-Cabrera et al., 2011).

These effects will likely continue to operate in the years following this study. Previous research showed that regeneration of Scots pine is a gradual process in disturbed forests of dry, inner-alpine valleys, taking up to 8-16 years after fire (Vacchiano et al., 2013), i.e., a longer window than in Mediterranean or Continental ecosystems (Bullock, 2009; Retana et al., 2012). After that time, the first post-disturbance cohort should reach sexual maturity (10 20 years in Scots pine: Vilà-Cabrera et al., 2011) and the regeneration process should occur more rapidly, thanks to seed dispersal from the newly matured seed trees. On the other hand, due to the opportunistic nature of the study, we could not assess the influence of seed and seedling predation on regeneration abundance. Previous experiments (Castro et al., 1999; Nystrand and Granstrom, 2000) found that seed predation (e.g., by carabids, birds, and microtine rodents) could determine up to $96 \%$ recruitment failures, and seedling predation 
(e.g. by slugs) from 5 to $100 \%$ mortality. Furthermore, the intensity of predation can interact with disturbance legacies, e.g., residual vegetative cover (Castro et al., 2002) or coarse woody debris (Nystrand and Granstrom, 2000).

One of the aims of our study was to ascertain the existence of a relationship between fireinduced soil changes and the establishment of Scots pine seedlings. Pine regeneration exhibited a preference for low-fertility $(\mathrm{C} / \mathrm{N}$ ratio: beta $=0.79)$, nutrient-poor $(\mathrm{K}$ saturation: beta $=-0.94$ ), and eroded soils (total clay: beta $=-0.90$ ). This result suggests that soil legacies produced by the high severity fire were potentially beneficial to Scots pine germination. However, their effect was undermined by the excessive distance from the seed source, and the likely extreme summer evaporation from the bare soil (e.g., Mendoza et al., 2009). Aggregate stability, on the other hand, did not play any significant effect on regeneration abundance. To this regard, we could not confirm results from previous studies, that had suggested that aggregate stability influences water movement into the soil profile, and therefore is beneficial to the restoration of vegetation cover, especially on dry sites (Ursino and Rulli, 2010). The establishment of Scots pine on poorer sites, and the absence of a preference for structurally better soils, could be favored at the study site by selection due to competitive advantage (or avoidance) versus other early-seral, rapid post-fire colonizers, such as aspen or birch (as in Moser et al., 2010).

\section{Conclusions}

We assessed the interplay of several ecosystem compartments (vegetation, soil, and disturbance) in determining the success of Scots pine regeneration in a dry, inner-alpine valley. This study highlighted: (1) that soils differed in some physical and chemical properties as a consequence of contrasting fire seve rities, although the event dated back to five years before sampling; (2) that fire severity significantly affected establishment of Scots pine via disturbance legacies (i.e., coarse woody debris, distance from seed trees) and soil legacies (i.e., soil texture, $\mathrm{C} / \mathrm{N}$ ratio, and $\mathrm{K}$ content). Our results suggest that the effect of high-severity fire (i.e., temperatures $>220^{\circ} \mathrm{C}$ lasting for several hours) on the topsoil are not per se detrimental to Scots pine regeneration. Rather, they can make new sites available to seedling establishment (high light, poor soil), provided that both dispersal distance and soil moisture are not limiting.

In the study area, Scots pine establishment was denser and taller under the intermediate severity fire, i.e., under a sparse canopy cover, in close vicinity of the seed source, and where the amount of residual coarse woody debris provided facilitated germination sites. This result 
suggests that post-fire logging should leave a sufficient amount of deadwood on the ground (e.g., by restraining from complete salvaging), in order to mitigate soil moisture losses and create microsites favorable to the establishment of regeneration following the fire.

Fuel reduction treatments can be used to mitigate fire behavior and effects, such as in inneralpine Scots pine stands subject to high fire risk. However, in the Alps it is difficult and/or socially unaccepted to create fuelbreaks large enough to slow down intense crown fires (Bovio, 2000). Therefore, the spatial otpimization of treated areas (e.g., Agee and Skinner, 2005) could be based on other criteria, such as maximizing seed dispersal from the surviving trees after fire by ensuring the survival of a sufficient number of "green islands" of seed trees in the forest.

\section{Acknowledgements}

We are thankful to Giancarlo Cesti from Nucleo Antincendi Boschivi, Corpo Forestale Regione Autonoma Valle d'Aosta, for logistic support and data provision, and to our field crew, including K. Fede and S. Catalano. We acknowledge J. Castro and one anonymous reviewer for their helpful comments on an earlier version of this manuscript. 


\section{Tables}

Table 1 - Effects of fire on soil at different temperatures (thresholds used in the text are in bold)

\begin{tabular}{|c|c|c|}
\hline Temperature $\left({ }^{\circ} \mathbf{C}\right)$ & Effects & Source \\
\hline $40-70$ & Protein degradation and death of living cells & (Precht et al., 1973) \\
\hline $48-54$ & Dehydration or death of roots & (Hare, 1961) \\
\hline $70-90$ & Death of seeds & (Martin et al., 1975) \\
\hline $80-90$ & Death of micorrhiza & (Pattinson et al., 1999) \\
\hline 60-120 & Death of soil microbes & (Neary et al., 1999) \\
\hline 127 & Soil sterilization & (Raison, 1979) \\
\hline $175-200$ & Potential increment in soil hydrophobicity & (DeBano, 1981) \\
\hline 220-380 & Incipient soil structural degradation & (Soto et al., 1991) \\
\hline $200-315$ & Incipient distillation of soil organic matter & (Neary et al., 1999) \\
\hline $200-400$ & $\mathrm{~N}$ volatilization & (Neary et al., 1999) \\
\hline $270-300$ & Disruption of soil hydrophobicity & (DeBano, 1981) \\
\hline 300 & Complete consumption of organic horizons & (Neary et al., 1999) \\
\hline $460-700$ & Loss of hydroxyl groups from clay minerals & (Giovannini et al., 1988) \\
\hline 450 & Complete consumption of soil organic matter & (Neary et al., 1999) \\
\hline 500 & Dehydroxilation of minerals & (Neary et al., 1999) \\
\hline 600 & Oxidation of metallic bonds & (Mataix-Solera and Guerrero, 2007) \\
\hline 600 & Sharp increase in sand, decrease silt and clay & (Ketterings et al., 2000) \\
\hline 760 & K volatilization & (Weast, 1988) \\
\hline 774 & $P$ volatilization & (Weast, 1988) \\
\hline 800 & $S$ volatilization & (Weast, 1988) \\
\hline 880 & Na volatilization & (Weast, 1988) \\
\hline 980 & Permanent alterations in clay minerals & (DeBano et al., 1977) \\
\hline 1107 & $\mathrm{Mg}$ volatilization & (Weast, 1988) \\
\hline 1000 & Degradation of carbonates & (Rabenhorst, 1988) \\
\hline 1240 & Ca volatilization & (Weast, 1988) \\
\hline
\end{tabular}


Table 2 - Fuel loadings computed from field sampling in supplementary fuel plots $(n=4)$ in the unburned forest and lab analysis

\begin{tabular}{lc}
\hline Fuel class & Fuel load $\left(\mathbf{t ~ h a}^{\mathbf{- 1}}\right)$ \\
\hline Litter & 4.42 \\
Duff & 70.67 \\
Dead $<0.6 \mathrm{~cm}$ & 1.63 \\
Dead 0.6-2.5 cm & 1.95 \\
Dead 2.5-7.5 cm & 4.45 \\
Dead $>7.5 \mathrm{~cm}$ & 3.31 \\
Grass & 0.02 \\
Small shrubs & 3.71 \\
Tree crown foliage & 7.41 \\
Branches & 5.19 \\
\hline
\end{tabular}


Table 3 - Mean (range) of site, soil cover, and pine regeneration variables in the four fire severity levels $(\mathrm{n}=5$ plots per level)

\begin{tabular}{|c|c|c|c|c|c|}
\hline & units & Unburned & $\begin{array}{l}\text { Moderate } \\
\text { severity }\end{array}$ & $\begin{array}{c}\text { Intermediate } \\
\text { severity }\end{array}$ & High severity \\
\hline elevation & m a.s.l. & $1230(1221-1249)$ & $1264(1247-1273)$ & $1287(1281-1291)$ & $1298(1291-1304)$ \\
\hline slope & $\%$ & $43(30-61)$ & $45(26-57)$ & $33(27-38)$ & $41(33-53)$ \\
\hline aspect & $\circ$ & $194(175-213)$ & $177(137-224)$ & $174(145-210)$ & $183(150-205)$ \\
\hline pre-fire tree density $(\mathrm{rcd}>7.5 \mathrm{~cm})$ & $h a^{-1}$ & $985(707-1559)$ & $1456(1415-1768)$ & $1061(354-2476)$ & $1485(707-2476)$ \\
\hline pre-fire mean tree rcd & $\mathrm{cm}$ & $15.4(13.8-20.1)$ & $13.2(11.2-16.0)$ & $18.4(13.0-20.4)$ & $21.6(14.3-28.0)$ \\
\hline distance from seed trees & $\mathrm{m}$ & $0(-)$ & $0(-)$ & $3.1(2-6)$ & $23.2(13-26)$ \\
\hline tree cover & $\%$ & $89.0(75-94)$ & $84.6(65-95)$ & $2.6(0-5)$ & $0(-)$ \\
\hline shrub cover & $\%$ & $1.7(0-7)$ & $0.2(0-1)$ & $2.8(0-10)$ & $10.8(0-50)$ \\
\hline herb cover & $\%$ & $34.2(3-57)$ & $38.8(10-66)$ & $62.4(40-92)$ & $45.8(17-71)$ \\
\hline rock and bare soil cover & $\%$ & $8.0(2-20)$ & $18.2(5-32)$ & $4.2(0-10)$ & $27.8(17-37)$ \\
\hline coarse woody debris cover & $\%$ & $1.2(0-5)$ & $1.2(0-4)$ & $8.4(2-15)$ & $5.2(1-10)$ \\
\hline seedlings per plot & count & $0(-)$ & $7.2(0-22)$ & $7.2(1-17)$ & $0.2(0-1)$ \\
\hline seedling height & $\mathrm{cm}$ & - & $4.4(0.5-17)$ & $12.5(1-66)$ & $50.0(-)$ \\
\hline seedling age & years & - & $1.4(1-3)$ & $2.1(1-4)$ & $4.0(-)$ \\
\hline yearly height growth & $\mathrm{cm}$ & - & $3.2(0.5-7)$ & $6.0(0.5-27)$ & $12.5(4-22)$ \\
\hline
\end{tabular}


Table 4 - GLM of pine seedling density (beta: standardized regression coefficients; $\mathrm{p}$ : statistical significance of predictor)

\begin{tabular}{|c|c|c|}
\hline & beta & $\mathbf{p}$ \\
\hline (intercept) & -0.180 & 0.676 \\
\hline tree cover & 0.036 & 0.875 \\
\hline coarse woody debris cover & 0.748 & 0.003 \\
\hline distance from seed trees & -2.233 & $<0.001$ \\
\hline clay & -0.902 & $<0.001$ \\
\hline $\mathrm{C} / \mathrm{N}$ & 0.789 & 0.001 \\
\hline K saturation & -0.942 & 0.085 \\
\hline
\end{tabular}




\section{Captions of figures}

Fig. 1 Study area, fire perimeters, and location of sampling plots. Coordinate system: UTM WGS 1984, zone 32 North (units: m)

Fig. 2 Peak temperature and duration of soil heating (minutes) obtained from FOFEM simulation of high, intermediate, and moderate severity fire

Fig. 3 Boxplot of soil variables in the unburned (UN), moderate (MO), intermediate (MH), and high (HI) severity fires (outliers were omitted), and results of Tukey's post-hoc test (p $=0.05)$. Boxes with no letters in common are significantly different from each other

Fig. 4 Permutation variable importance (percent incMSE) of selected predictors in the random forest algorithm 


\section{References}

Agee JK. Fire and pine ecosystems. In: Richardson DM, editor. Ecology and biogeography of Pinus. Cambridge: Cambridge University Press; 1998. p.193-218.

Agee JK, Skinner CN. Basic principles of forest fuel reduction treatments. For Ecol Manage 2005;211:83-96.

Albini FA, Alexander ME, Cruz MG. A mathematical model for predicting the maximum potential spotting distance from a crown fire. Int J Wildland Fire 2012; 21:609-27.

Ascoli D, Castagneri D, Valsecchi C, Conedera M, Bovio G. Post-fire restoration of beech stands in the Southern Alps by natural regeneration. Ecol Eng 2013;54:210-7.

Baer SG, Heneghan L, Eviner VT. Applying soil ecological knowledge to restore ecosystem services. In: Wall DH, Bardgett RD, Behan-Pelletier V, editors. Soil ecology and ecosystem services. Oxford: Oxford University Press; 2012. p. 377-93.

Barbeito I, Fortin MJ, Montes F, Canellas I. Response of pine natural regeneration to smallscale spatial variation in a managed Mediterranean mountain forest. J Veg Sci 2009;12:488-503.

Bastias BA, Xu Z, Cairney JWG. Influence of long-term repeated prescribed burning on mycelial communities of ectomycorrhizal fungi. New Phytol 2006;172:149-58.

Beard KH, Vogt KA, Vogt DJ, Scatena FN, Covich AP, Sigurdardottir R et al. Structural and functional responses of a subtropical forest to 10 years of hurricanes and droughts. Ecol Monographs 2005;75:345-61.

Bento-Gonçalves A, Vieira A, Úbeda X, Martin D. Fire and soils: Key concepts and recent advances. Geoderma 2012;191:3-13.

Bogorodskaya AV, Ivanova GA, Tarasov PA. Post-fire transformation of the microbial complexes in soils of larch forests in the lower Angara River region. Eurasian Soil Sci 2011;44:49-55.

Bovio G. La protezione dagli incendi boschivi nelle Alpi centro-occidentali. Schweiz Z Forstwesen 2000;151:325-35.

Breiman L. Random forests. Machine Learning 2001;45:5-32.

Bullock, JM. A long- term study of the roles of competition and facilitation in the establishment of an invasive pine following heathland fires. J Ecol 2009;97:646-56.

Castro J, Allen CD, Molina-Morales M, Marañón-Jiménez S, Sanchez-Miranda A, Zamora R. Salvage logging versus the use of burnt wood as a nurse object to promote post-fire tree seedling establishment. Restor Ecol 2011;19:537-544.

Castro J, Gómez JM, García D, Zamora R, Hódar JA. Seed predation and dispersal in relict Scots pine forests in southern Spain. Plant Ecol 1999;145:115-23. 
Castro J, Puerta-Piñero C, Leverkus AB, Moreno-Rueda G, Sánchez-Miranda A. Post-fire salvage logging alters a key plant-animal interaction for forest regeneration. Ecosphere 2012;3:art90.

Castro J, Zamora R, Hódar JA. Mechanisms blocking Pinus sylvestris colonization of Mediterranean mountain meadows. J Veg Sci 2002;13:725-31.

Castro J, Zamora R, Hódar JA, Gomez JM. Seedling establishment of a boreal tree species (Pinus sylvestris) at its southernmost distribution limit: Consequences of being in a marginal Mediterranean habitat. J Ecol 2004;92:266-77.

Certini G. Effects of fire on properties of forest soils: a review. Oecologia 2005;143:1-10.

Certini G, Nocentini C, Knicker H, Arfaioli P, Rumpel C. Wildfire effects on soil organic matter quantity and quality in two fire-prone Mediterranean pine forests. Geoderma 2011;167-8:148-55.

Cesti G. Fattori orografici e meteorologici influenti sugli incendi boschivi. Quart: Musumeci; 2011.

Cesti G, Cerise A. Aspetti degli incendi boschivi. Quart: Musumeci; 1992.

Chandler C, Cheney P, Thomas P, Trabaud L, Williams D. Fire in forestry. Forest fire behavior and effects. Chichester: John Wiley \& Sons; 1983.

Covington WW, Sackett SS. Fire effects on ponderosa pine soils and their management implications. In: Krammes JS, editor. Effects of fire management of Southwestern natural resources. Proceedings of the Symposium. Fort Collins CO: USDA Forest Service, Rocky Mountain Forest and Range Experiment Station; 1990. p. 105-11.

Curlevski NJA, Artz RRE, Anderson IC, Cairney JWG. Response of soil microbial communities to management strategies for enhancing Scots pine (Pinus sylvestris) establishment on heather (Calluna vulgaris) moorland. Plant and Soil 2011;339:413-24.

DeBano LF. The effect of fire on soil properties. In: Harvey CA, Neuenschwander LF, editors. Symposium on Management and Productivity of Western-Montane Forest Soils. Ogden, UT: USDA Forest Service, Intermountain Research Station; 1991. p. 151-6.

DeBano LF. Water repellent soils: a state-of-the-art. Berkeley, CA: USDA Forest Service, Pacific Southwest Forest and Range Experiment Station; 1981.

DeBano LF, Dunn PH, Conrad CE. Fire's effect on physical and chemical properties of chaparral soils. In: Mooney HA, Conrad CE, Moll EJ, McKenzie B, McLachlan D, Vetez $\mathrm{R}$ et al., editors. Proceedings of the Symposium on the Environmental Consequences of Fire and Fuel Management in Mediterranean Ecosystems. Palo Alto, CA: USDA Forest Service; 1977. p. 65-74.

Dexter AR, Richard G, Arrouays D, Czyz $\square$ EA, Jolivet C, Duval O. Complexed organic matter controls soil physical properties. Geoderma 2008;144:620-7.

Doerr SH, Shakesby RA, MacDonald LH. Soil water repellency: A key factor in post-fire erosion. In: Cerdà A, Robichaud PR, editors. Fire effects on soils and restoration strategies. Enfield, NH: Taylor \& Francis; 2010. p. 197-223. 
Dorren LKA Berger F, Imeson AC, Maier B, Rey F. Integrity, stability and management of protection forests in the European Alps. For Ecol Manage 2004;195:165-76.

Dryness CT, Youngberg CT, Ruth RH. Some effects of logging and slash burning on physical soil properties in the Corvallis watershed. Portland, OR: USDA Forest Service, Pacific Northwest Forest and Range Experiment Station; 1957.

Fernandes PM, Vega GA, Jiménez E, Rigolot E. Fire resistance of European pines. For Ecol Manage 2008; 256:246-55.

Foster DR, Knight DH, Franklin JF. Landscape patterns and legacies resulting from large, infrequent forest disturbances. Ecosystems 1998; 1:497-510.

Gee GW, Bauder JW. Particle-size analysis. In: Klute A, editor. Methods of Soil Analysis: Part 1-Physical and Mineralogical Methods. Madison, WI: Soil Science Society of America and American Society of Agronomy; 1986. p. 383-411.

Genuer R, Poggi JM, Tuleau-Malot C. Variable selection using random forests. Pattern Recognition Letters 2010;31:2225-2236.

Giardina CP, Rhoades CC. Clear cutting and burning affect nitrogen supply, phosphorus fractions and seedling growth in soils from a Wyoming lodgepole pine forest. For Ecol Manage 2001;140:19-28.

Gimmi U, Wohlgemuth T, Rigling A, Hoffmann C, Bürgi A. Land-use and climate change effects in forest compositional trajectories in a dry central- alpine valley. Ann For Sci 2010;67:701.

Giovannini G, Lucchesi S, Giachetti M. Effect of heating on some physical and chemical parameters related to soil aggregation and erodibility. Soil Sci 1988;146:255-61.

González-Pérez JA, González-Vila FJ, Almendros G, Knicker H. The effect of fire on soil organic matter-a review. Environ Int 2004;30:855-70.

Gómez-Rey MX, Couto-Vázquez A, García-Marco S, González-Prieto SJ. Impact of fire and post-fire management techniques on soil chemical properties. Geoderma 2013;1956:155-64.

Granged AJP, Jordán A, Zavala LM, Muñoz-Rojas M, Mataix-Solera J. Short-term effects of experimental fire for a soil under eucalyptus forest (SE Australia). Geoderma 2011;167:125-34.

Greene EF, Johnson EA. Wind dispersal of seeds from a forest into a clearing. Ecology 1966;77: 595-609.

Greene EF, Johnson EA. Secondary dispersal of tree seeds on snow. J Ecol 1997;85:329-40.

Griffin JM, Turner MG. Changes to the N cycle following bark beetle outbreaks in two contrasting conifer forest types. Oecologia 2012;170:551-65.

Habrouk A, Retana J, Espelta JM. Role of heat tolerance and cone protection of seeds in the response of three pine species to wildfires. Plant Ecol 1999;145:91-9. 
Hancock MH, Amphlett A, Proctor R, Dugan D, Willi J, Harvey P et al. Burning and mowing as habitat management for capercaillie Tetrao urogallus: an experimental test. For Ecol Manage 2011;262:509-21.

Hancock MH, Summers RW, Amphlett A, Willi J. Testing prescribed fire as a tool to promote Scots pine Pinus sylvestris regeneration. Eur J For Res 2009;128:319-33.

Hare RC. Heat effects on living plants.New Orleans, LA: USDA Forest Service, Southern Forest Experiment Station; 1961.

Hartford RA, Frandsen WH. When it's hot, it's hot... Or maybe it's not! (Surface flaming may not portend extensive soil heating). Int J Wildl Fire 1992;2:139-44.

Hille MG. Fire ecology of Scots pine in Northwest Europe. PhD dissertation. Wageningen: Wageningen Universiteit; 2006.

Hille MG, den Ouden J. Improved recruitment and early growth of Scots pine (Pinus sylvestris L.) seedlings after fire and soil scarification. Eur J For Res 2004;123:213-8.

Jayen K, Leduc A, Bergeron Y. Effect of fire severity on regeneration success in the boreal forest of northwest Quebec, Canada. Ecoscience 2006;13:143-51.

Jordán A, Zavala LM, Mataix-Solera J, Nava AL, Alanís N. Effect of fire severity on water repellency and aggregate stability on Mexican volcanic soils. Catena 2011;84:136-47.

Kavdır Y, Ekinci H, Yüksel O, Mermut AR. Soil aggregate stability and ${ }^{13} \mathrm{C}$ CP/MAS-NMR assessment of organic matter in soils influenced by forest wildfires in Çanakkale, Turkey. Geoderma 2005;129:219-29.

Keane RE, Dillon G, Jain T, Hudak A, Morgan P, Karau E et al. The problems with fire severity and its application in fire management; 2012. Online document. URL: http://www.firelab.org/ResearchProject_Files/ijwf_sev_text.pdf. Accessed August 20 ${ }^{\text {th }}$, 2013.

Keeley JE. Fire intensity, fire severity and burn severity: a brief review and suggested usage. Int J Wildl Fire 2009;18:116-26.

Keller T, Dexter AR. Plastic limits of agricultural soils as functions of soil texture and organic matter content. Soil Res 2012;50:7-17.

Ketterings QM, Bigham JM, Laperche V. Changes in soil mineralogy and texture caused by slash-and-burn fires in Sumatra, Indonesia. Soil Sci Soc Am J 2000;64:1108-17.

Kipfer T, Moser B, Egli S, Wohlgemuth T, Ghazoul J. Ectomycorrhizal succession patterns in Pinus sylvestris forests after stand-replacing fire in the Central Alps. Oecologia 2011;167: 219-22.

Kutiel P, Naveh Z. The effect of fire on nutrients in a pine forest soil. Plant and Soil 1987;104:269-74.

Leverkus AB, Puerta-Piñero C, Guzmán JR, Navarro J, Castro J. Post-fire salvage logging increases restoration costs in a Mediterranean mountain ecosystem. New Forests 2012;43:601-13. 
Liaw A, Wiener M. randomForest: Breiman and Cutler's random forests for classification and regression. Version 4.6.7.; 2012. Online document. URL:

http://CRAN.R- project.org/package=randomForest. Accessed August 22 $2^{\text {th }}, 2013$.

Llovet J, Ruiz-Valera M, Josa R, Vallejo VR. Soil responses to fire in Mediterranean forest landscapes in relation to the previous stage of land abandonment. Int J Wildl Fire 2009;18:222-32.

Lutes DC. FOFEM 6.0 User Guide; 2013. Online document. URL: www.firelab.org/ScienceApps_Files/downloads/FOFEM/FOFEM6_Help.pdf. Accessed July $30^{\text {th }}, 2013$

Lynham TJ, Wickware GM, Mason JA. Soil chemical changes and plant succession following experimental burning in immature jack pine. Can J Soil Sci 1998;78:93-104.

Mallik AU, Gimingham CH, Rahman AA. Ecological effects of heather burning. 1. Water infiltration, moisture retention and porosity of surface soil. J Appl Ecol 1984;72:767-76.

Mangas VJ, Sanchez JR, Ortiz C. Effects of a fire on runoff and erosion on Mediterranean forest soils in SE Spain. Pirineos 1992;140:37-51.

Marañón-Jiménez S, Castro J, Fernández-Ondoño E, Zamora R. Charred wood remaining after a wildfire as a reservoir of macro- and micronutrients in a Mediterranean pine forest. Int J Wildland Fire 2013a;22:681-95.

Marañón-Jiménez S, Castro J, Querejeta JI, Fernández-Ondoño E, Allen CD. Post-fire wood management alters water stress, growth, and performance of pine regeneration in a Mediterranean ecosystem. For Ecol Manage 2013b;308:231-39.

Marañón-Jiménez S, Castro J. Effect of decomposing burnt wood on soil fertility and nutrient availability in a Mediterranean ecosystem. Biogeochemistry 2013;112:519-35.

Marozas F, Armolaitis K, Aleinikovien J. Changes of ground vegetation, soil chemical properties and microbiota following the surface fires in Scots pine forest. J Env Eng 2013;21:67-75.

Martin RE, Miller RL, Cushwa CT. Germination response of legume seeds subjected to moist and dry heat. Ecology 1975;56:1441-5.

Martín A, Díaz-Raviña M, Carballas T. Short- and medium-term evolution of soil properties in Atlantic forest ecosystems affected by wildfires. Land Degradation Devel 2011;23:427-39.

Marzano R, Garbarino M, Marcolin E, Pividori M, Lingua E. Deadwood anisotropic facilitation on seedling establishment after a stand-replacing wildfire in Aosta Valley (NW Italy). Ecol Eng 2013;51:117-22.

Mataix-Solera J, Cerdà A, Arcenegui V, Jordán A, Zavala LM. Fire effects on soil aggregation: A review. Earth Sci Rev 2011;109:44-60.

Mataix-Solera J, Guerrero C. Efectos de los incendios forestales en las propiedades edáficas. In: Mataix-Solera J, editor. Incendios Forestales, Suelos y Erosión Hídrica. Alicante: Caja Mediterráneo and CEMACAM Font Roja-Alcoi; 2007. p. 6-40. 
Mataix-Solera J, Navarro MA, Zornoza R, Guerrero C, Gómez I, García-Orenes F et al. Fire effects on soil organic carbon in turn affecting physical, chemical and biochemical soil properties. Geophys Res Abs 2008;10:EGU2008-A-01280.

Matías L, Gómez-Aparicio L, Zamora R, Castro J. Effects of resource availability on plant recruitment at community level: an integrated analysis using structural equation modelling. Perspect Plant Ecol Evol Syst 2011;13:277-85.

Moser B, Temperli C, Schneiter G, Wohlgemuth T. Potential shift in tree species composition after interaction of fire and drought in the Central Alps. Eur J For Res 2010;129:625-33.

Mendoza I, Zamora R, Castro J. A seeding experiment for testing tree-community recruitment under variable environments: implications for forest regeneration and conservation in Mediterranean habitats. Biol Conserv 2009;142:1491-9.

Mills AJ, Fey MV. Frequent fires intensify soil crusting: physicochemical feedback in the pedoderm of long-term burn experiments in South Africa. Geoderma 2004;121:45-64.

Mirov NT. The genus Pinus. New York: Ronald Press; 1967.

Neary DG, Klopatek CC, DeBano LF, Ffolliott PF. Fire effects on belowground sustainability: a review and synthesis. For Ecol Manage 1999;122:51-71.

Niklasson M, Granstrom A. Numbers and sizes of fires: long-term spatially explicit fire history in a Swedish boreal landscape. Ecology 2000;81:1484-99.

Nyman B. Studies on the germination in seeds of Scots pine (Pinus silvestrys L.) with special reference to the light factor. Studia Forestalia Suecica 1963;2:1-159.

Nystrand O, Granström A. Predation on Pinus sylvestris seeds and juvenile seedlings in Swedish boreal forest in relation to stand disturbance by logging. J Appl Ecol 2000;37:449-63.

Ordóñez JL, Retana J, Espelta JM. Effects of tree size, crown damage, and tree location on post-fire survival and cone production of Pinus nigra trees. For Ecol Manage 2005;206:109-17.

Ottmar RD, Sandberg DV, Riccardi CL, Prichard SJ. An overview of the Fuel Characteristic Classification System-Quantifying, classifying, and creating fuelbeds for resource planning. Can J For Res 2007;37:2383-93.

Pattinson GS, Hammill KA, Sutton BG, McGee PA. Simulated fire reduces the density of arbuscular mycorrhizal fungi at the soil surface. Mycological Res 1999;103:491-6.

Pérez-Cabello F, Ibarra P, Echeverría MT, de la Riva J. Post-fire land degradation of Pinus sylvestris L. woodlands after 14 years. Land Degradation Devel 2010;21:145-60.

Peterson CJ, Leach A. Salvage logging after windthrow alters microsite diversity, abundance and environment, but not vegetation. Forestry 2008;81:361-76.

Peterson CJ, Pickett STA. Forest reorganization: a case study in an old-growth forest catastrophic blowdown. Ecology 1995;76:763-74. 
Pezzatti GB, Zumbrunnen T, Bürgi M, Ambrosetti P, Conedera M. Fire regime shifts as a consequence of fire policy and socio-economic development: An analysis based on the change point approach. For Policy Econ 2013;29:7-18.

Pyne SJ, Andrews PL, Raven RD. Introduction to Wildland Fire, 2nd Edition. New York, Wiley; 1996.

Pickett STA, White PS. The ecology of natural disturbance and patch dynamics. New York: Academic Press; 1985.

Precht JJ, Chrispherson HH, Larcher W. Temperature and life. New York: Springer; 1973.

Rabenhorst MC. Determination of organic and carbonate carbon in calcareous soils using dry combustion. Soil Sci Soc Am J 1988;52:965-8.

Raison RJ. Modification of the soil environment by vegetation fires, with particular reference to nitrogen transformations: A review. Plant and Soil 1979;51:73-108.

Retana J, Arnan X, Arianoutsou M, Barbati A, Kazanis D, Rodrigo A. Post-fire management of non-serotinous pine forests. In: Moreira F, Arianoutsou M, Corona P, De las Heras J, editors. Post-fire management and restoration of southern European forests. Berlin: Springer; 2012. p. 151-70.

Rhoades JD. Cation exchange capacity. In: Page AL, Miller RH, Keeney DR, editors. Methods of soil analysis: Chemical and microbiological properties. Madison, WI: American Society of Agronomy; 1982. p. 149-57.

Riaño D, Chuvieco E, Condés S, González-Matesanz J, Ustin SL. Generation of crown bulk density for Pinus sylvestris L. from LiDAR. Remote Sens Environ 2004;92:345-52.

Rodrigo A, Retana J, Picó FX. Direct regeneration is not the only response of Mediterranean forests to large fires. Ecology 2004;85:716-29.

Schimmel J, Granstrom A. Fire severity and vegetation response in the boreal Swedish forest. Ecology 1996;77:1436-50.

Seybold CA, Herrick JE, Brejda JJ. Soil resilience: a fundamental component of soil quality. Soil Science 1999;164:224-34.

Shakesby RA. Post-wildfire soil erosion in the Mediterranean: Review and future research directions. Earth Sci Rev 2011;105:71-100.

Società Italiana di Scienza del Suolo. Metodi di analisi chimica del suolo. Milano: Franco Angeli; 2000.

Soto B, Benito E, Díaz-Fierros F. Heat-induced degradation processes in forest soils. Int J Wildl Fire 1991;1:147-52.

Stanchi S, Godone D, Belmonte S, Freppaz M, Galliani C, Zanini E. Land suitability map for mountain viticulture: a case study in Aosta Valley (NW Italy). J Maps 2013a;9:1-6. 
Stanchi S, Freppaz M, Godone D, Zanini E. Assessing the susceptibility of alpine soils to erosion using soil physical and site indicators. Soil Use Manage 2013b; in press. DOI: 10.1111/sum.12063.

Stanchi S, Freppaz M, Oberto E, Caimi A, Zanini E. Plastic and liquid limits in Alpine soils: methods of measurement and relation to soil properties. In: Dazzi C, Costantini E, editors. The soils of tomorrow: soils changing in a changing world. Reikirchen: Catena; 2008a. p. 593-604.

Stanchi S, Bonifacio E, Zanini E, Perfect E. Chemical and physical treatment effects on aggregate breakup in the 0 to $2 \mathrm{~mm}$ size range. Soil Sci Soc Am J 2008b;72:1418-21.

Stanchi S, Freppaz M, Zanini E. The influence of Alpine soil properties on shallow movement hazards, investigated through factor analysis. Nat Hazards Earth Syst Sci 2012;12:1845-54.

Stocks BJ, Alexander ME, Wotton BM, Stefner, MD Flannigan CN, Taylor SW et al. Crown fire behaviour in a northern jack pine - black spruce forest. Can J For Res 2004;34:15481560 .

Storaunet KO, Rolstad J, Toeneiet M, Blanck Y. Strong anthropogenic signals in historic forest fire regime: a detailed spatiotemporal case study from south-central Norway. Can J For Res 2013;43:836-45.

Ursino N, Rulli MC. Combined effect of fire and water scarcity on vegetation patterns in arid lands. Ecol Model 2010;221:2353-62.

Úbeda X, Bernia S, Simelton E. The long-term effects on soil properties from a forest fire of varying intensity in a Mediterranean environment. In: Garcia C, Batalla RJ, editors. Catchment Dynamics and River Processes - Mediterranean and Other Climate Regions. Amsterdam: Elsevier; 2005. p. 87-102.

Valese E. Applicazione del Canadian Forest Fire Weather Index System nel contesto della Grande Regione Alpina (GAR): potenzialità e problematiche. PhD dissertation. Padua: Università degli Studi di Padova; 2008.

Vacchiano G, Lonati M, Berretti R, Motta R. Drivers of Pinus sylvestris L. regeneration following small, high-severity fire in a dry, inner-alpine valley. Plant Biosystems 2013; in press. DOI:10.1080/11263504.2013.819821.

Valette JC, Gomendy V, Maréchal J, Houssard C, Gillon D. Heat transfer in the soil during very low-intensity experimental fires: the role of duff and soil moisture content. International Journal of Wildland Fire 1994;4:225-237.

Vanninen P, Mäkelä A. Carbon budget for Scots pine trees: effects of size, competition and site fertility on growth allocation and production. Tree Physiol 2005;25:17-30.

Van Wagner CE. Conditions for the start and spread of crown fire. Can J For Res 1977;7:2334.

Van Wagner CE. The development and structure of the Canadian Forest Fire Weather Index System. Ottawa: Canadian Forest Service; 1987. 
Vilà-Cabrera A, Rodrigo A, Martínez-Vilalta J, Retana J. Lack of regeneration and climatic vulnerability to fire of Scots pine may induce vegetation shifts at the southern edge of its distribution. J Biogeogr 2011;39:488-96.

Wan S, Hui D, Luo Y. Fire effects on nitrogen pools and dynamics in terrestrial ecosystems: a meta-analysis. Ecol Applications 2001;11:1349-65.

Warren WG, Olsen PF. A line intersect technique for assessing logging waste. For Sci 1964;10:267-76.

Wastl C, Schunk C, Lüpke M, Cocca G, Conedera M, Valese E et al. Large-scale weather types, forest fire danger, and wildfire occurrence in the Alps. Agric For Meteorol 2013;168:15-25.

Weast RC. Handbook of chemistry and physics. Boca Raton: CRC Press; 1988.

White PS, Jentsch A. Disturbance, succession, and community assembly in terrestrial plant communities. In: Temperton VR, Hobbs R, Nuttle T, Halle S, editors. Assembly rules and restoration ecology: Bridging the gap between theory and practice. Washington, DC: Island Press; 2004. p. 342-66.

Zanini E, Bonifacio E, Albertson JD, Nielsen DR. Topsoil aggregate breakdown under watersaturated conditions. Soil Science 1998;163:288-98.

Zumbrunnen T, Pezzatti GB, Menéndez P, Bugmann H, Bürgi M, Conedera M. Weather and human impacts on forest fires: 100 years of fire history in two climatic regions of Switzerland. For Ecol Manage 2011;261:2188-99. 





Figure 2

Click here to download high resolution image

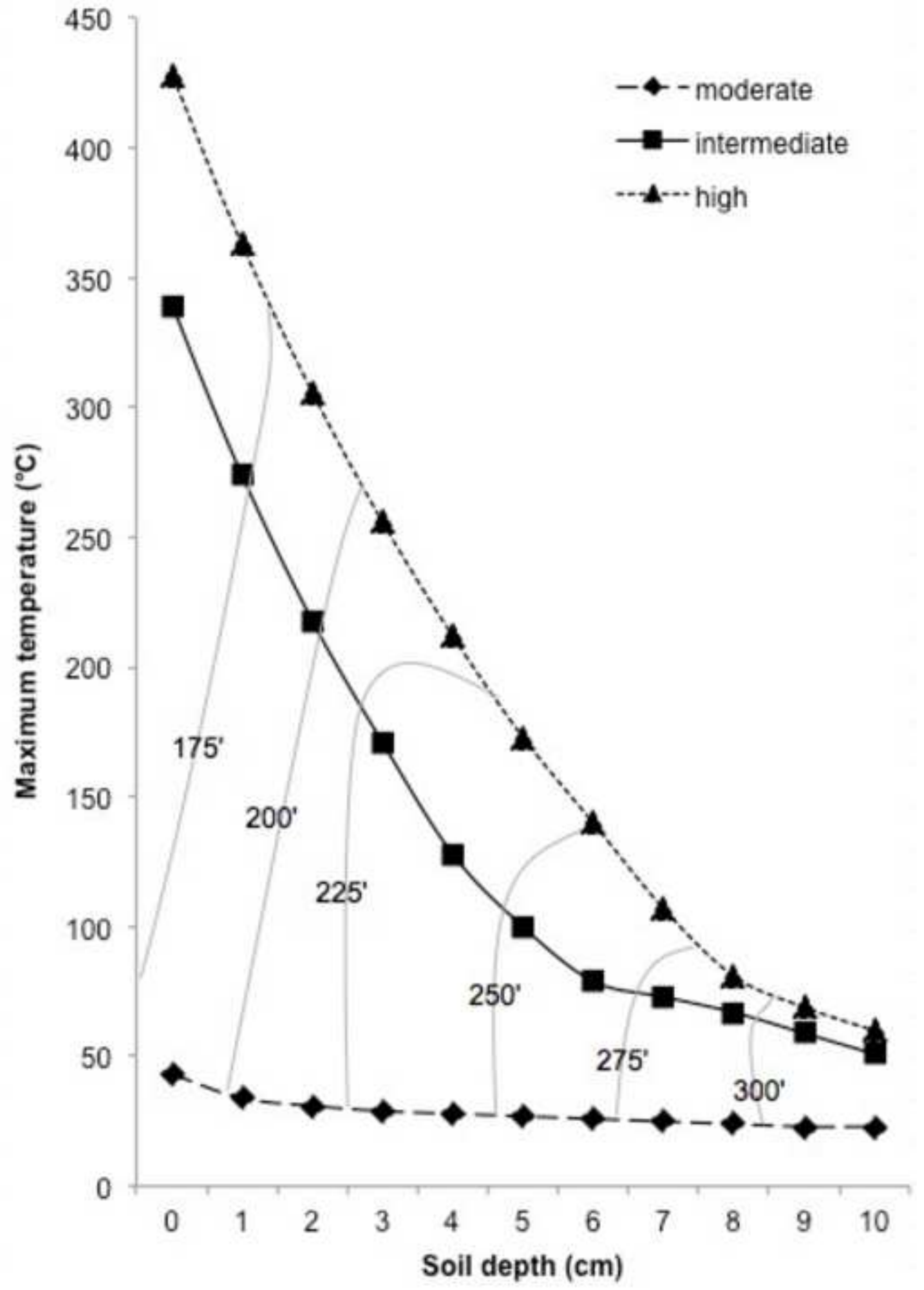


A) SOIL TEXTURE
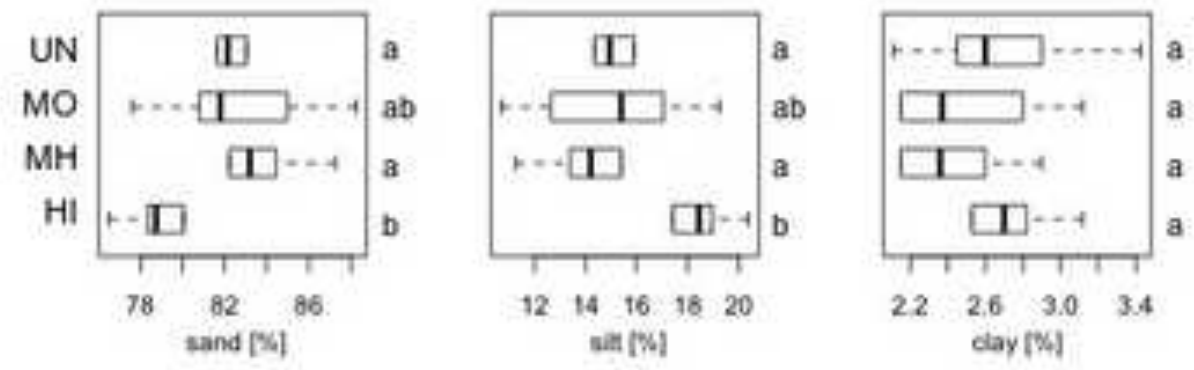

B) PHYSICAL PROPERTIES
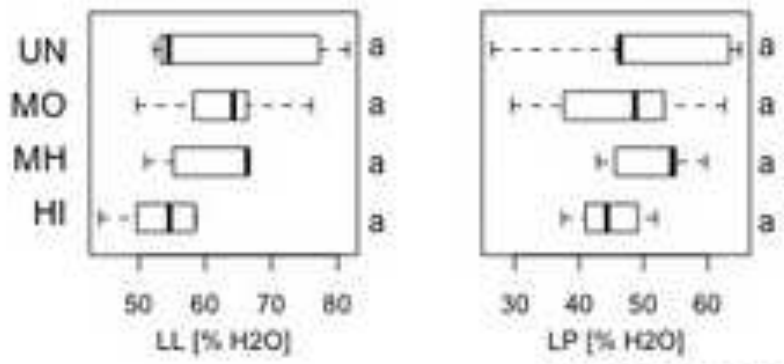

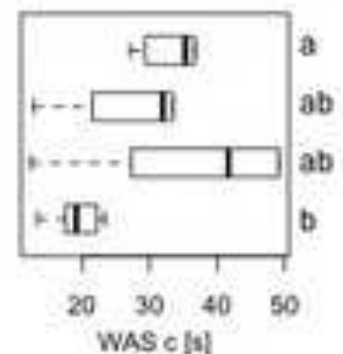

C) CHEMICAL PROPERTIES

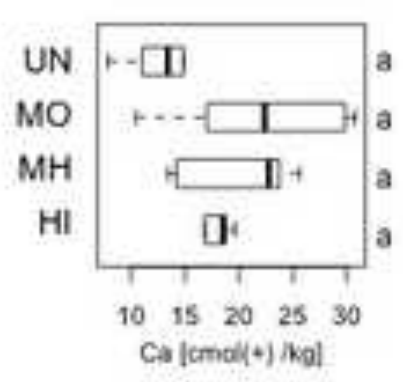

Ca $|c m a l(+) / \mathrm{kal}|$
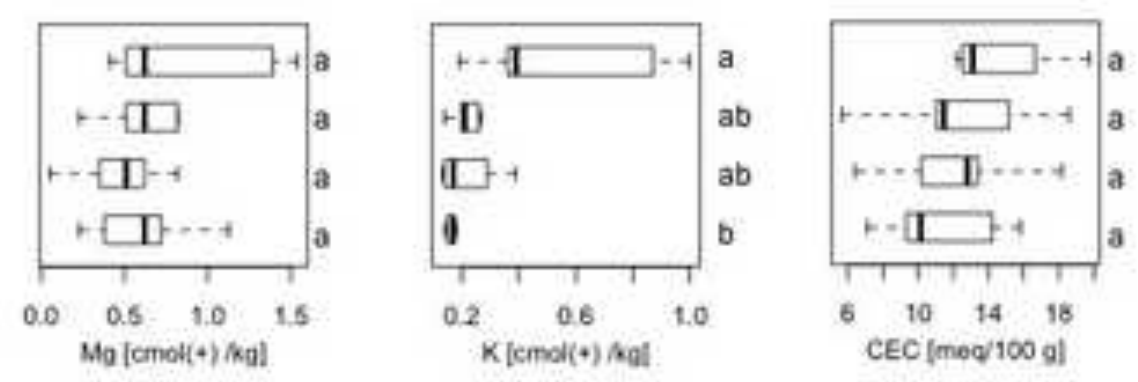

D) ORGANIC MATTER
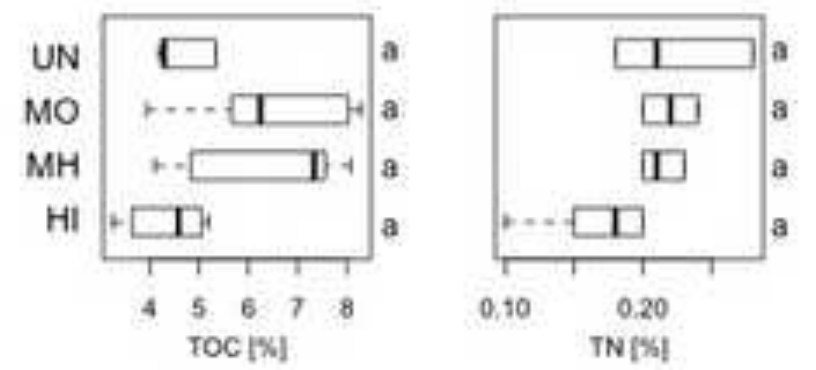



ond [-]

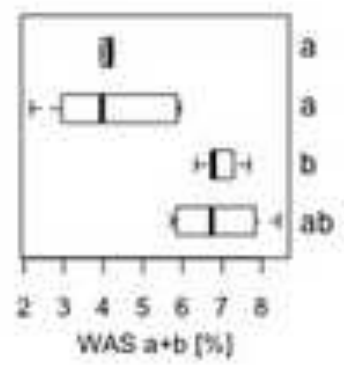

345.67
WAS $a+b[3]$

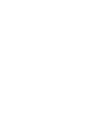




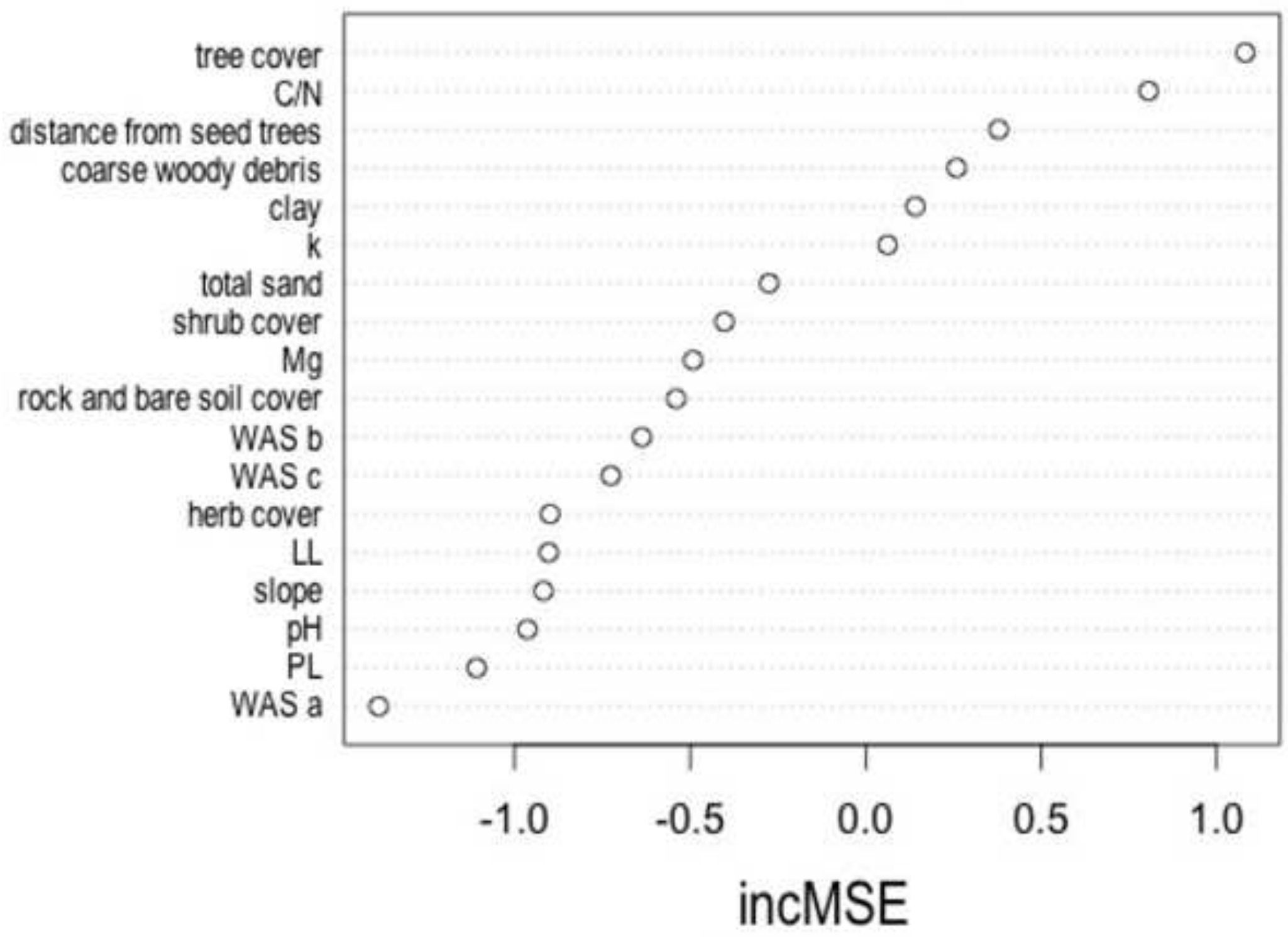


Dipartimento di Scienze Agrarie, Forestali e Alimentari

Via Leonardo Da Vinci, 44 - 10095 Grugliasco (TO)
Science of the Total Environment

Editorial Office

\section{Conflict of interest disclosure form}

Article Title .....Fire severity, residuals and soil legacies affect regeneration of Scots pine in the Southern Alps

Authors .......G Vacchiano, S Stanchi, G Marinari, D Ascoli, E Zanini, R Motta......

I certify that there is no actual or potential conflict of interest in relation to this article. If any conflict exists, please define hereafter:

Conflict (if none, "None" or describe financial interest/arrangement with one or more organizations that could be perceived as a real or apparent conflict of interest in the context of the subject of this article): .......None.

Name

Giorgio Vacchiano (Corresponding author)

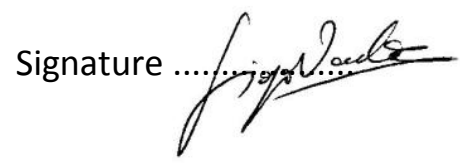

Date . ...25 $5^{\text {th }}$ September 2013.......... 